\title{
Stable 'portrait' of breast tumors during progression: data from biology, pathology and genetics
}

\author{
M Lacroix, $R$-A Toillon and G Leclercq
}

Laboratoire Jean-Claude Heuson de Cancérologie Mammaire, Institut Jules Bordet, Université Libre de Bruxelles, 127 boulevard de Waterloo, B-1000 Bruxelles, Brussels, Belgium

(Requests for offprints should be addressed to M Lacroix; Email: Marc.Lacroix@ulb.ac.be)

\begin{abstract}
It is widely believed that ductal breast cancer dissemination involves a succession of clinical and pathological stages starting with carcinoma in situ, progressing into invasive lesion and culminating in metastatic disease. Such changes have frequently been attributed to the sequential acquisition of various alterations in a single cell followed by clonal selection and expansion, thus leading to intratumor diversity. According to this multi-step view, extensive genotype and phenotype (marker expression, grade) shift may occur in the same tumor during progression; this may lead to the coexistence of molecularly and/or pathologically different areas within the same lesion. An increasing amount of data of various natures now appear to challenge this concept: only a few distinct 'portraits', in relation to estrogen receptor (ER) status and grade, may be found among tumors. Moreover, although undergoing increasing genetic alteration, most individual lesions largely maintain their phenotype when they evolve from in situ to the metastatic state. While many of the data presented here are related to ductal tumors, lobular cancer is also discussed.
\end{abstract}

Endocrine-Related Cancer (2004) 11 497-522

\section{Introduction}

In Western countries, about 1 in 11 women will develop a breast carcinoma, generally of ductal origin. Despite considerable progress in the knowledge of tumor biology and treatment, more than two-thirds of patients still succumb to the disease. In most cases, death results from metastasis of breast cancer cells (BCCs). Elucidating the mechanisms that ultimately confer metastatic properties to BCCs remains, therefore, a major research challenge.

It has been widely believed that breast cancer dissemination involves a sequential progression through clinical and pathological stages starting with carcinoma in situ, progressing into invasive carcinoma and culminating in metastasis. To explain the transition from one stage to another, a multi-step hypothesis has been proposed. Based on the fact that BCCs are genetically unstable, the hypothesis postulates that tumor-stage changes are associated with the sequential acquisition of various genetic and, consequently, phenotypic alterations in a single cell followed by clonal selection and expansion. The successive clonal populations are thought to acquire an increasing aggressiveness, with numerous alterations in properties such as proliferation, adhesion, proteolysis, motility, angiogenic ability etc. and loss of estrogen receptor (ER). It is also believed that considerable intratumor diversity may result from the co-existence of these clonal populations. In particular, the characteristics of metastatic cells are expected to often be significantly different from those observed in BCCs in situ.

In fact, a number of recent data-of pathological, molecular and genetic nature-have revealed that despite increasing genetic alteration, the 'portrait' of breast tumors remains amazingly stable during progression, and that no major change appears to explain why a tumor may progress to the metastatic stage. A series of these data are reviewed here. 


\section{Phenotype studies in breast tumors- molecular markers and grade}

Before examining the occurrence of phenotype changes during tumor progression, it is necessary to specify which phenotype categories will be considered here. The categories are based on: (1) a series of molecular markers related to ER status; (2) grade. The rationale behind this choice is that both ER status and grade have long been used to classify tumors. As a consequence, there is abundant literature examining correlations between them and other parameters such as marker expression or proliferation. A classification based on an ER-positive/ ER-negative or a low-grade/high-grade dichotomy hardly suffices to describe the complex spectrum of breast tumors; however, its simplicity will facilitate our main purpose: evaluating the stability of the breast tumor 'portrait'.

\section{Molecular markers}

ER appears as a major discriminator in the molecular classification of breast tumors. As a mediator of (anti)estrogen action, its key role in the biology and treatment of breast cancer is well established. ER level has been evaluated in tumors for more than 30 years (Leclercq et al. 2002). The receptor, encoded by the ESRl gene, was long believed to be unique, until an isoform named ER-beta and encoded by a specific gene, ESR2, was identified. The 'older' isoform, subsequently named ER-alpha, seems to be functionally the most important in breast tumors (Speirs 2002). We have shown that the ER protein content, evaluated in breast tumors by a ligand-binding assay which measures both ER-alpha and -beta isoforms, was linearly correlated with the level of mRNA specific for ESR1, while the ESR2 mRNA was undetectable in samples (Lacroix et al. 2001). Here, ER-beta will be considered as being of secondary importance in breast tumors, and the term ER will refer to the alpha isoform, unless otherwise indicated. ER is expressed by about 60 $80 \%$ of breast tumors ('ER-positive'), while $20-40 \%$ are considered ER-negative.

During the last decade, many genes and/or proteins with an expression level positively or negatively correlated to that of ER have been identified in tumors. A series of these genes are listed in Table 1a (positive correlation to ER) and b (negative correlation to ER). From these studies, it appeared that two highly different phenotypes could be found in breast tumors according to their ER status. In addition, the co-existence in the same tumor of markers related to both ER-positive and ER-negative phenotypes was rarely observed. For instance, it is well known that ER and epidermal growth factor receptor (EGFR) levels are inversely correlated in most ductal tumors. Both receptors are, however, occasionally coexpressed in lesions, but are then, in the vast majority of cases, localized in distinct tumor cells, or in interspersed groups of cells ('mosaic expression', as described for instance in van Agthoven et al. 1994). Whether ER-poor/ EGFR-rich BCCs were derived from ER-rich/EGFRpoor cells in these tumors is unknown. If this was the case, the observations suggest that such an event is infrequent and does not seem to be related to any significant advantage for progression. Rare co-expressions have also been observed with other pairs of markers related to distinct BCC phenotypes (not discussed here).

A series of proliferation/apoptosis-related markers has also been measured in tumors. In general, their expression levels reflected the fact that mitotic/apoptotic activity is higher in ER-negative than in ER-positive lesions (Keshgegian \& Cnaan 1995, Gandhi et al. 1998, Lipponen 1999). For instance, the expression of the apoptosis inhibitor BCL2 was correlated to that of ER (Gee et al. 1994, Binder et al. 1995, Yang et al. 1999). P53 levels were repeatedly found to be higher in ER-negative lesions (see notably Rudolph et al. 1999a). Proliferation markers KI-67 and topoisomerase II alpha levels were also positively correlated to ER-negative status (Molino et al. 1997, Rudolph et al. 1999b). Regarding cyclins, while cyclin E was associated with the absence of ER, the inverse was observed for cyclin D1 (Nielsen et al. 1997, Barnes \& Gillett 1998, Reed et al. 1999, Spyratos et al. 2000, Park et al. 2001, Loden et al. 2002). The level of the cyclin-dependent kinases inhibitors $1 \mathrm{~A}$ (P21 $\left.{ }^{\mathrm{WAF} 1 / \mathrm{CIP} 1}\right)$ and $1 \mathrm{~B}\left(\mathrm{P} 27^{\mathrm{KIP} 1}\right)$ was found to be higher in ER-positive tumors (Barbareschi 1999, Reed et al. 1999, Barbareschi et al. 2000, Oh et al. 2001).

The evaluation of multiple markers in multiple tumor samples has recently been facilitated by the use of tissue micro-arrays (TMAs) (Kononen et al. 1998, Camp et al. 2000, Simon et al. 2004). In general, TMA-based data are in good agreement with previous observations. For instance, TMA analysis was applied to 107 breast carcinomas samples, to assess the pattern of expression of ER, PR, P53, ERBB2, MYC, P27 ${ }^{\mathrm{KIP} 1}$, cyclin D, cyclin E, BCL2, MIB1, MCM2 (minichromosome maintenance protein 2, see Gonzales et al. 2003), basal cytokeratins CK5/6, epithelial cytokeratins CK8/18. Cluster analysis of the data classified samples into two main groups: the first ('ER-related') included about two-thirds of the tumors and was characterized by a high expression level of ER, PR, BCL2, cyclin D, P27 ${ }^{\mathrm{KIP} 1}, \mathrm{CK} 8 / 18, \mathrm{MYC}$; the second group expressed relatively high levels of P53, ERBB2, CK5/6, and of the proliferation markers MCM2, MIB, and cyclin E (Callagy et al. 2003). In another study, 15 markers (ER, PR, P53, ERBB2, EGFR, cyclin A, cyclin D1, cyclin E, BCL2, P21 ${ }^{\mathrm{WAF} 1 / \mathrm{CIP} 1}, \mathrm{P} 27^{\mathrm{KIP} 1}, \mathrm{CK} 5 / 6, \mathrm{CK} 8 /$ 


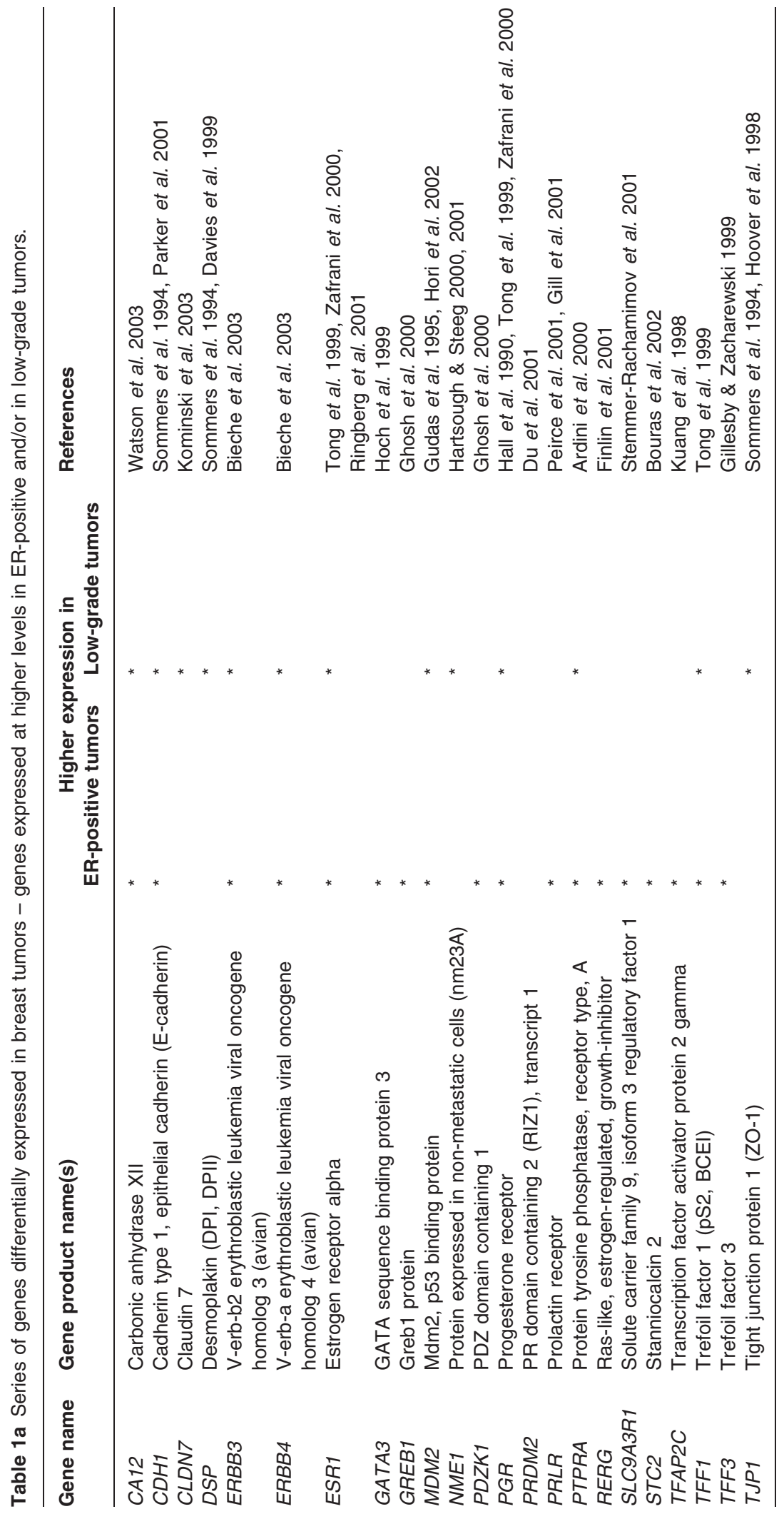




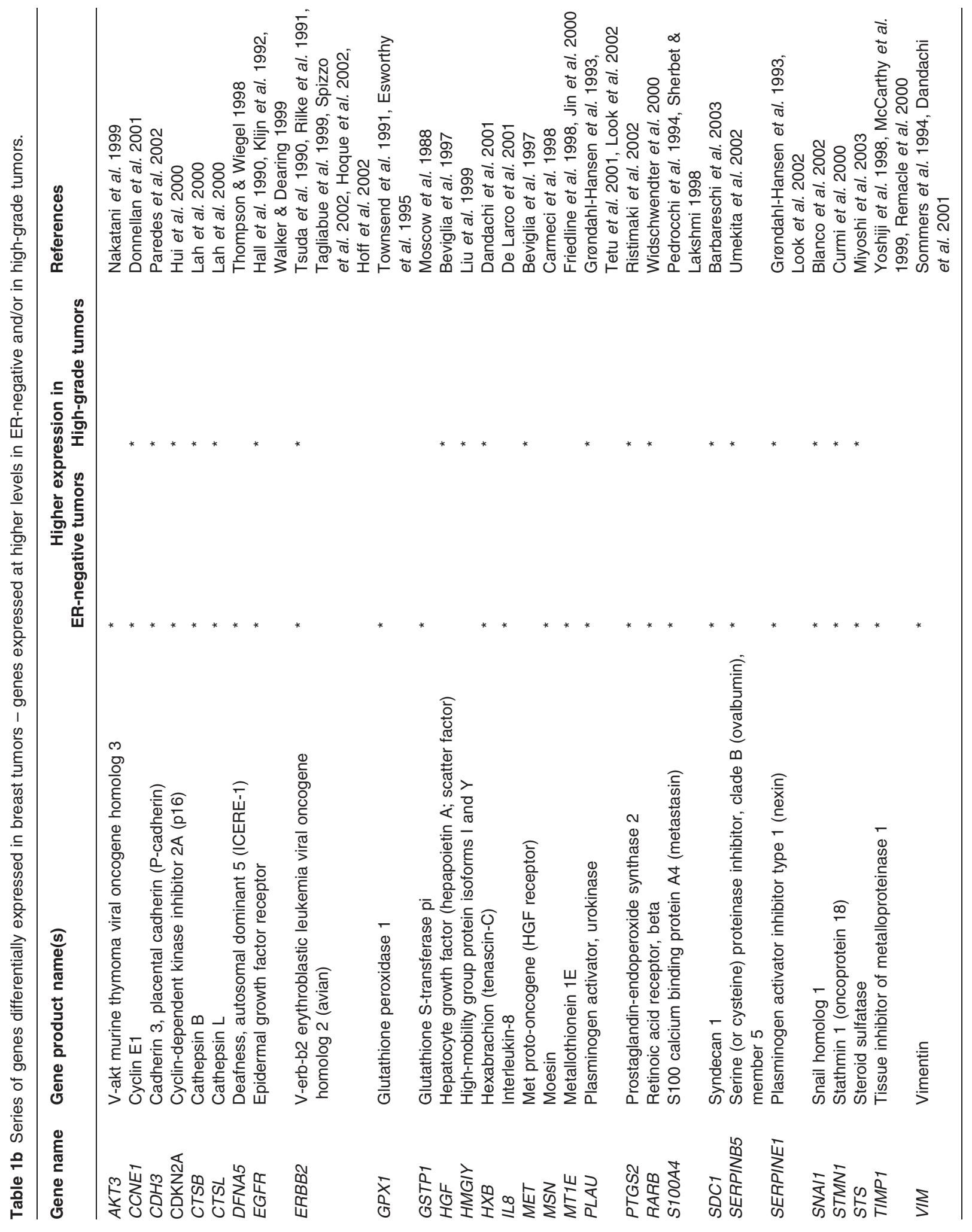


18 and SMA (smooth muscle actin)) were evaluated in 166 breast cancer samples. Tumors expressing the basal CK5/6 showed higher levels of cyclin A, KI-67, P53 and EGFR expression; tumors expressing CK8/18 but not CK5/6 were associated with a higher level of ER, PR, $\mathrm{P} 21^{\mathrm{WAF} 1 / \mathrm{CIP} 1}, \mathrm{P} 27^{\mathrm{KIP} 1}, \mathrm{ERBB} 2$ and BCL2. When cluster analysis was applied to the data, three classes were found. Besides those defined by the presence or absence of CK $5 / 6$, a third class appeared which was characterized by ERBB2 over-expression and ERBB2 amplification (Korsching et al. 2002). Thus, a specific 'portrait' may occasionally be associated with ERBB2-overexpressing tumors. This is also found in DNA-micro-array-based gene expression studies (see Micro-array studies in section on Genetic studies on breast tumors).

\section{Grade}

One of the most widely accepted classification systems for breast carcinomas is grading. The majority of grading systems, such as those based on the Scarff, Bloom and Richardson (SBR) method, combine histological assessment of nuclear pleomorphism, mitotic activity and tubule formation (Elston \& Ellis 2002). Tumors classified as 'grade I' or 'low grade' have well-differentiated attributes, while 'grade III' or 'high-grade' tumors have poorly differentiated attributes. Grade II tumors fall into an intermediate category. High-grade ductal carcinoma have been associated with the highest rate of local recurrence $(25-30 \%)$, low-grade tumors have very low recurrence $(0-5 \%)$, while intermediate-grade tumors have a recurrence rate somewhere in between (10-15\%) in 12 years of median follow-up (Polyak 2001). Moreover, highgrade tumors recur within a shorter time than the lowgrade ones (for instance, in Cserni (2002), the median recurrence time is 88,42 and 23 months for grades I, II and III respectively).

Grading is not directly based on molecular expression profiles. It may thus be asked whether or not grades are associated with the expression of specific sets of tumor markers, and more precisely if they are correlated to the distinct ER-status phenotypes described above for tumors. It has been repeatedly reported that most ERpositive tumors are of low grade. Conversely, high-grade tumors are mainly ER-negative (see for instance Tong et al. 1999, Zafrani et al. 2000, Ringberg 2001). Unsurprisingly, several markers whose expression is positively correlated to that of ER in tumors have also been associated with low-grade tumors; these are listed in Table 1a. Conversely, high-grade tumors are characterized by the expression of markers more related to the ER profiles in tumors; these are listed in Table 1b. None of the genes positively correlated to ER in tumors were found associated with high-grade/poorly differentiated carcino- mas. None of the genes negatively correlated to ER in $\mathrm{BCC}$ in tumors was found associated with low-grade/welldifferentiated lesions.

Proliferation/apoptosis-related markers appear to reflect the fact that mitotic/apoptotic activity is higher in high-grade/poorly differentiated tumors. For instance, a study examining mitotic index (MI, number of mitoses/ 1000 nuclei) and apoptotic index (AI, number of apoptosis/1000 nuclei) found MI and AI values to be up to 20-fold and 2.5-fold higher, respectively, in poorly differentiated ductal carcinoma in situ (DCIS), as compared with well-differentiated DCIS (Buerger et al. $2000 a$ ). This is in line with results from other groups (Keshgegian \& Cnaan 1995, Gandhi et al. 1998). For instance, in an immunohistochemical (IHC) study of 46 DCIS, it was shown that BCL2 was expressed in $12 / 12$, $14 / 20$ and $1 / 14$ well-, moderately and poorly differentiated tumors respectively. For P53, the respective values were $0 / 12,6 / 20$ and 12/14, while for KI-67 (Viacava et al. 1999) they were $0 / 12,10 / 20$ and $14 / 14$. In another report, KI-67 expression was found in only $5 \%$ of low-grade but in $70 \%$ of high-grade DCIS. For P53, the respective percentages were $5 \%$ and $50 \%$ (Krishnamurthy \& Sneige 2002). Regarding cyclins, while cyclin E has been associated with high-grade tumors, the inverse was observed for cyclin D1 (Loden et al. 2002). The level of P21 2 WAF1/CIP1 and $\mathrm{P} 27^{\mathrm{KIP} 1}$ was found to be higher in low-grade or welldifferentiated tumors (Barbareschi 1999, Reed et al. 1999, Wu et al. 1999, Oh et al. 2001, Barbareschi et al. 2000).

The relationship between marker expression and grade has also been investigated by TMA analysis (see below). For instance, in a study of 107 breast cancer samples, the expression of 11 markers showed an association with grade: ER, PR, BCL2, P27 ${ }^{\mathrm{KIP} 1}$ and cyclin D levels were higher in low-grade samples; ERBB2, P53, cyclin E, CK5/6, MCM2 and MIB1 levels were higher in high-grade tumors (Callagy et al. 2003). These results are in agreement with previous data.

\section{Concluding remarks on molecular markers and grade}

A number of studies have shown that the phenotype categories based on ER status and on grade largely overlap. ER-positive and well-differentiated/low-grade tumors on the one hand, and ER-negative and poorly differentiated lesions on the other hand, share many features. But the two phenotypes defined in each category (ER-positive and -negative, well and poorly differentiated) appear highly different, so that a frequent transition from one to the other during progression seems rather unlikely. However, this does not exclude the possiblity that co-expression of the two phenotypes could occasionally occur in the same lesion, as suggested by the 
existence of grade II tumors. However, it is largely unknown whether such cases result from phenotype changes during tumor growth, or are derived from two populations that appeared early in tumorigenesis.

\section{Macroscopic homogeneity of breast tumors - stable 'portrait' during progression}

According to the multi-step view, progression from primary to metastatic tumor should be accompanied by the sequential acquisition of phenotype changes, allowing BCCs to invade, disseminate and colonize distant sites. Notably, it has been proposed that BCCs in vivo might undergo a transition from the ER-positive- to the ERnegative-associated phenotype. Along the same lines, it has been repeatedly proposed that tumor progression is characterized by a shift from the well-differentiated/lowgrade to the poorly differentiated/high-grade phenotype. Nevertheless, most investigations have revealed that progression is not accompanied by major changes in marker expression or grade.

\section{Progression to invasiveness and markers/grade}

If we hypothesize that progression from in situ to invasive carcinoma is often accompanied by extensive phenotype changes, it should then be easy to find in a significant part of invasive tumors both ER-positive- and ER-negativeassociated, and both low- and high-grade, compartments. ER-negative-associated markers and high-grade areas should normally be observed more frequently in the invasive than in the in situ tumor compartment. In fact, most studies examining this point have revealed a striking similarity between both parts of breast carcinomas (Lampejo et al. 1994, Moriya \& Silverberg. 1994, Iglehart et al. 1995, Douglas-Jones et al. 1996, Millis et al. 1998, Foster et al. 2000, Mommers et al. 2001 Warnberg et al. 2001,). For instance, grade and tumor marker (P53, ERBB2, KI-67, ER, PR, BCL2 and angiogenesis) expression were compared in 194 pure DCIS, 127 small invasive lesions and 305 lesions with both an invasive and in situ component. Grade concordance was high between in situ and invasive components of the same tumor. All markers were found to correlate with grade rather than with invasiveness. No marker was clearly associated with the progression from in situ to invasiveness. The expression of tumor markers was similar, at $80-90 \%$, in the two components of mixed lesions (Warnberg et al. 2001). The DNA content and the expression of ERBB2 were examined simultaneously in both non-invasive and invasive phases of primary breast cancers, by image analysis. DNA content in the intraductal and invasive components was virtually identical. Expression of ERBB2 was similar in both growth phases, strongly suggesting identity of the ERBB2 genotype (Iglehart et al. 1995). An IHC study examined the expression of proteins involved in proliferation and apoptosis (KI-67, cyclin D1, ERBB2, $\mathrm{P} 21^{\mathrm{WAF} 1 / \mathrm{CIP} 1}, \mathrm{P} 27^{\mathrm{KIP} 1}, \mathrm{P} 53$ and BCL2) in 61 DCIS and 53 invasive lesions. More proliferation tended to be observed in invasive cancers. However, well-differentiated DCIS and invasive lesions shared many aberrations in expression of the proliferation-associated proteins, as did poorly differentiated DCIS and invasive lesions. In contrast, many differences were observed between the well- and poorly differentiated lesions (Mommers et al. 2001). In a study of 102 patients, a 67\% concordance in grade was found between in situ and infiltrating components (Millis et al. 1998). Another study of 64 cases indicated an $86 \%$ grade concordance between both components (Moriya \& Silverberg. 1994). These studies and others (Lampejo et al. 1994, Douglas-Jones et al. 1996) indicated a strong correlation between the grade of DCIS and the grade of infiltrating carcinoma in which both components were present.

It is thus striking that patterns of grade or the other markers did not seem to change significantly during the transition from in situ to invasive carcinoma. Invasive cancer seems to occur independently of tumor grade. This is further supported by comparative genetic hybridization and micro-array data (see below).

\section{Recurrence, metastasis}

Metastatic and recurrent BCCs are often believed to have accumulated phenotypic alterations, as they are associated with late stages in tumor progression. In addition, metastatic cells may colonize various tissues that are highly different from the breast (bone, lung, brain, etc.) after having completed all steps of a complex process including local invasion, intravasation, resistance to blood pressure, adhesion to blood vessels, and extravasation. This suggests that they have sequentially acquired specific adaptive properties and it has thus been hypothesized that metastatic and recurrent cells could express a phenotype significantly different from that observed in the primary tumor.

Attempts have been made to compare the expression of various markers and/or the histological grade in primary tumors and their corresponding metastases and/ or recurrences. It was shown that CK8 and CK19 expression were similar in both primary carcinomas and their lymph node (LN) metastases (Su et al. 1996). In an IHC study of $38 \mathrm{LN}$ metastases and their corresponding primaries, very good concordance was found for KI-67 (85\%), ER (96\%), PR (82\%), P53 (76\%) and ERBB2 
(84\%) (Briffod et al. 2000). In another comparative IHC study involving $102 \mathrm{LN}$ metastases, an $80 \%$ concordance was found for ER (Nedergaard et al. 1995). Investigations on a total of 31 LN, 35 lung, 25 skin, 1 liver and 2 contralateral breast metastases revealed good concordance with primaries for ER, PR, P53 and ERBB2 (Barnes et al. 1988, Kayser et al. 1998, Shimizu et al. 2000). This was also the case for ER, PR and EGFR evaluated in $26 \mathrm{LN}$ and 2 distant metastases. In this latter study, expression of ER and EGFR was inverse regarding the individual tumor cells in both primary tumors and metastases (van Agthoven et al. 1995). By ligand-binding assay, it has been estimated that no more than $20 \%$ of the ER-positive primary tumors will produce ER-negative metastases. It has even been established that the expression of the frequent ER-alpha variant transcripts is conserved in primary tumors and their matched, concurrent $\mathrm{LN}$ metastases (Fuqua 2001). A good concordance was also found for grade; for instance, a study of 102 primaries and LN metastases revealed that both had the same grade (I, II or III) in $79 \%$ of cases (Millis et al. 1998). In a tissue micro-array analysis, it was found that $77 \%$ of ERBB2positive primary tumors had entirely ERBB2-positive LN metastases, $6.5 \%$ had entirely ERBB2-negative metastases and $16.5 \%$ had a mixture of ERBB2-positive and ERBB2-negative metastases. For ERBB2-negative primary tumors, a $95 \%$ concordance was found for the $\mathrm{LN}$ metastases. Moreover, the ERBB2 status within individual tumors was fairly homogenous, as was the status of primary tumors and their metastases (Simon et al. 2001).

Along the same lines, several studies have examined grade and marker (ER-alpha, ER-beta, PR, P53, ERBB2 and TFF1 (formerly pS2)) expression in recurrent breast cancers (Millis et al. 1998, Horiguchi et al. 2000, Shimizu et al. 2000, Bijker et al. 2001, Jensen et al. 2001). Good concordance was found in most cases; for instance, in an analysis of 116 cases of recurrence, only four patients were found to have developed poorly differentiated DCIS or grade III invasive carcinoma after well-differentiated DCIS (Bijker et al. 2001). Regarding ER-alpha and ERbeta, their expression was even found to be higher in recurrences than in the corresponding primaries (Jensen et al. 2001). In a study of six cases of recurrence, histological type was the same as the initial one. There was concordance in ER, PR, TFF1, ERBB2 and P53 status between the recurrence and the primary cancer (Horiguchi et al. 2000). In a study of 49 primaries and recurrences, a $78 \%$ grade (I, II or III) concordance was found; in 36 patients who developed both metastasis and recurrence, grade concordance between them was also $78 \%$ (Millis et al. 1998). In an analysis of 84 patients for which axillary metastases and/or local and/or regional recurrence(s) were found, 78 and $81 \%$ concordance was demonstrated between primaries and their metastases and first recurrences respectively. In the cases where successive (up to six) recurrences were found, there was still a $74 \%$ concordance between the last recurrence and the initial tumor sample (Cserni 2002).

\section{Conclusions}

In conclusion, breast tumor phenotype does not appear, in most cases, to change extensively during tumor progression from in situ carcinoma to secondary site colonization. However, nearly all of the studies described here showed percentages of concordance in the 65-95\% range. This indicates the existence of a substantial number of cases in which progression (to invasiveness, to metastasis or recurrence) is accompanied by qualitative changes in marker expression or grade. The fact that BCCs could occasionally undergo profound phenotype alterations has been suggested for years. For instance, it has been proposed that epithelial-mesenchymal transition (EMT) could occur in BCCs. This process would be reminiscent of the transition that is observed during embryonic development at precise times and locations (Boyer et al. 2000). EMT in BCCs would consist of the turning-off of genes encoding epithelial markers (ERalpha, PR, E-cadherin, tight junction proteins etc.) and the increase of markers such as vimentin. While the reality of EMT has been little substantiated in vitro, the possibility that it could happen in vivo cannot be definitely excluded.

\section{Genetic studies on breast tumors}

\section{Karyotype and cytogenetic studies}

Breast cancer is characterized by multiple genetic alterations. They may include whole chromosome copy gain or loss (aneuploidy), gain and loss of parts of chromosomes (detected by comparative genetic hybridization and loss of heterozygosity analysis), amplifications or deletions of single genes, insertions and translocations, and mutations of a single or a few nucleotide(s).

\section{Aneuploidy}

Aneuploidy is frequent in breast carcinomas. In a study of 127000 breast tumors, about one-half were found to be diploid or near diploid, the others exhibiting various types of aneuploidy (Wenger et al. 1993). In an analysis of 256 patients, 384 modal chromosome numbers were detected, ranging between 29 and $211 ; 74 \%$ of these modal numbers were between 41 and $50,19 \%$ between 51 and 80 . Only $3 \%$ were lower than 41 and $4 \%$ higher than 80 (Teixeira et al. 2002). Our cumulative study of breast tumor series (Ried et al. 1995, Schwendel et al. 1998, Adeyinka et al. 1999, 
Roylance et al. 1999, Davidson et al. 2000, Dellas et al. 2002, Zudaire et al. 2002) emphasized that monosomy was observed mainly for chromosomes 7, 19, 20 and X, while trisomy most frequently concerned chromosomes 4 , 18, 19 and X. By analyzing a set of relatively small and partly overlapping series of BCC lines (Forozan et al. 1999, 2000, Kytola et al. 2000, Davidson et al. 2000, Larramendy et al. 2000), the same variations were observed, except that loss of chromosome $\mathrm{X}$ was relatively less frequent in cell lines. As most available cultured BCC lines are of metastatic origin, this suggests that the qualitative pattern of whole chromosome losses and gains remains constant during tumor progression. But what about the quantitative pattern?

Fluorescence in situ hybridization (FISH) analysis of chromosomes 7, 8, 16 and 17 was applied to foci of residual DCIS and a representative area of co-existing invasive neoplasm. Most hybridization pairs (7/12, 58\%) showed a gain in chromosomal copy number between the in situ and corresponding invasive area, whereas 29\% showed no apparent change and 13\% showed loss in copy number. Hybridizations from areas of invasive carcinoma, thus, were more frequently characterized by tumor cells with trisomy/polysomy (78\%) than neoplastic cells from residual DCIS (50\%) and less frequently characterized by cells with monosomy (10\% versus $16 \%)$. Even when DCIS cells exhibited chromosome trisomy, $65 \%$ of hybridizations demonstrated a significantly greater proportion of trisomic cells in the corresponding invasive population (Mendelin et al. 1999). In another FISH study, a high proportion (54\%) of 214 invasive breast carcinomas displayed aneusomy of chromosome 17. Aneusomy was not associated with survival, suggesting that it is not significantly related to the development of metastases. In contrast, an association was found with grade III carcinoma and ER negativity (Watters et al. 2003).

Indeed, although several FISH studies have attempted to identify chromosome gain or loss responsible for breast tumorigenesis and progression, no specific alterations can yet be repeatedly attached to certain histopathological stage. On the other hand, the patterns of aneuploidy may differ according to tumor grade. For instance, in a FISH study of numerical alterations of chromosomes 7, 8, 16 and 17 in 28 DCIS, grade I lesions were characterized by a complete lack of significant chromosome gain, but $29 \%$ showed partial (focal) monosomy. Grade III lesions, in contrast, showed partial or complete trisomy/polysomy in $88 \%$ hybridizations versus monosomy in only $4 \%$. Grade II DCIS exhibited a mixed pattern of chromosome aneuploidy: 38\% hybridizations were disomic, 36\% trisomic/polysomic and $26 \%$ monosomic ( 8 out of 10 hybridizations showing complete monosomy occurred in grade II lesions). In morphologically heterogenous lesions, higher-grade foci were characterized by chromosome copy gain relative to corresponding lower-grade areas in 17 of $22(77 \%)$ hybridizations (Visscher et al. 2000).

In conclusion, despite the fact that most tumors tend to gain chromosomes during progression, a higher proportion of high-grade carcinomas are believed to progress to near-triploidy (Pandis et al. 1996). However, no specific chromosome number change has been as yet clearly associated with progression.

An important criticism that is often addressed to karyotype analysis is that it may be biased, at least when it is applied to long-term cell cultures. The resulting karyotypes may represent minor malignant cell clones of the tumors expressing a growth advantage in culture (see for instance Truong et al. 1999). It is also possible that some of the simple abnormal karyotypes might be due to mitoses of non-malignant breast lesions (Lundin \& Mertens 1998, Persson et al. 1999). This underlines the need for additional techniques to detect genetic alterations.

\section{Comparative genomic hybridization (CGH) studies}

In addition to changes in chromosome number, DNA losses or gains larger than $10 \mathrm{mb}$ have been detected in tumors by CGH. Table 2 reports the frequency of DNA losses or gains affecting the ten most involved chromosome arms, as determined from a cumulative set of breast tumors (Ried et al. 1995, Schwendel et al. 1998, Adeyinka et al. 1999, Roylance et al. 1999, Davidson et al. 2000, Loveday et al. 2000, Guenther et al. 2001, Zudaire et al. 2002, Cingoz et al. 2003). These data have been confirmed by a recent study of 305 unselected primary invasive breast tumors, according to which the six most commonly observed gains were on 1q (55\%), 8q (41\%), 16p (40\%), $17 \mathrm{q}(28 \%), 20 \mathrm{q}(19 \%)$ and $11 \mathrm{q}(16 \%)$ and the three most commonly observed losses were on 13q (27\%), 16q (22\%) and 8p (18\%) (Rennstam et al. 2003).

Several studies using CGH analysis on DCIS have demonstrated a large number of chromosomal alterations

Table 2a Chromosome arms most frequently altered in a cumulative series of 542 breast tumors (CGH analysis), in order of decreasing frequency - DNA losses

\begin{tabular}{rrrrrrrrrr}
\hline $\mathbf{1 6 q}$ & $\mathbf{1 p}$ & $\mathbf{8 p}$ & $\mathbf{1 3 q}$ & $\mathbf{1 1 q}$ & $\mathbf{1 7 p}$ & $\mathbf{2 2 q}$ & $\mathbf{6 q}$ & $\mathbf{X p}$ & $\mathbf{X q}$ \\
\hline $25 \%$ & $21 \%$ & $20 \%$ & $19 \%$ & $19 \%$ & $18 \%$ & $17 \%$ & $14 \%$ & $11 \%$ & $11 \%$ \\
\hline
\end{tabular}

Table 2b DNA gains

\begin{tabular}{llllllllll}
$\mathbf{1 q}$ & $\mathbf{8 q}$ & $\mathbf{1 7 q}$ & $\mathbf{2 0 q}$ & $\mathbf{1 6 p}$ & $\mathbf{1 1 q}$ & $\mathbf{1 2 q}$ & $\mathbf{7 q}$ & $\mathbf{6 q}$ & $\mathbf{3 q}$ \\
\hline $51 \%$ & $46 \%$ & $24 \%$ & $24 \%$ & $22 \%$ & $21 \%$ & $17 \%$ & $15 \%$ & $15 \%$ & $15 \%$ \\
\hline
\end{tabular}


including gains on 1q, 6q, 8q, 17q, 19q, 20q and Xq, and losses on 13q, 16q, 17p and 22q. Most of these alterations resemble those identified in invasive ductal carcinoma (IDC), adding weight to the idea that DCIS is a direct precursor lesion of IDC (Aubele et al. 2002).

It has been shown that DNA loss at $16 \mathrm{q}$ is less frequent in high-grade ductal carcinoma (Roylance et al. 1999, 2002, Richard et al. 2000, Boecker et al. 2001, Cingoz et al. 2003) and in ER-negative tumors (Zudaire et al. 2002). This constitutes a strong argument against the theory supporting a frequent tumor progression from low to high grade and from ER-positive to ER-negative status. Indeed, it appears unlikely that grade III tumors could arise from grade I tumors through a process involving regain of $16 \mathrm{q}$. Besides similar observations on 16q, Richard et al. (2000) also noted a higher frequency of $7 q$ gains in ER-negative carcinomas and of $3 q$ gains in ER-negative and high-grade carcinomas, as well as a lower frequency of $16 \mathrm{p}$ gains in ER-negative tumors and of 22q losses in ER-negative and high-grade carcinomas. In an analysis of 22 tumors (DCIS and IDC), ER positivity was significantly higher in cases displaying $16 \mathrm{q}$ losses and 20q gains (Cingoz et al. 2003). Other investigators pointed out that, contrasting with the higher global frequency of chromosome changes in high-grade carcinomas, $16 \mathrm{q}$ losses were more frequent in low-grade carcinomas, while the frequency of $20 \mathrm{q}$ gains was the same in both low- and high-grade lesions (Boecker et al. 2001). Thus, while several qualitative differences have been highlighted by $\mathrm{CGH}$ in ER-positive/low-grade tumors, as compared with ER-negative/high-grade lesions, only one change, loss at $16 \mathrm{q}$, has been repeatedly observed. Whether it is crucially involved in phenotype definition is unlikely, as not all ER-positive/low-grade tumors are characterized by this loss, while it is occasionally observed in ER-negative/high-grade tumors.

Total DNA changes were found to be 1.7 -fold more frequent in ER-negative than in ER-positive tumors (Richard et al. 2000), while between 1.5- and 3.2-fold more genetic alterations were observed in grade III/highgrade/poorly differentiated than in grade I/low-grade/ well-differentiated samples (Schwendel et al. 1998, Roylance et al. 1999, 2002, Buerger et al. 2000a, Richard et al. 2000). For instance, amplification of ERBB2 (17q12), TOP2A (17q24), MYC (8q23), and CCND1 (11q13) was more frequently found in high- than in low-grade tumors. However, major amplifications in pure in situ carcinoma and in intraductal carcinoma with an invasive component did not differ (Glockner et al. 2001). That no specific gross DNA alteration was associated with invasion was confirmed by analysis of a series of ductal (but also lobular) tumors submitted to $\mathrm{CGH}$ following microdissection (Buerger et al. 2000b).

\section{Loss of heterozygosity ( $\mathrm{LOH}$ ) studies}

LOH analysis detects allelic loss at specific loci by a PCRbased screening with polymorphic microsatellite markers spaced across the region of interest. This technique has been widely used to detect the loss of putative suppressor genes.

$\mathrm{LOH}$ in breast cancer has been observed in multiple chromosomal regions, notably 1p, 1q, 3p, 6q, 7q, 8p, 9p, $11 \mathrm{q}, 13 \mathrm{q}, 16 \mathrm{q}, 17 \mathrm{p}, 17 \mathrm{q}, 18 \mathrm{q}$ and $22 \mathrm{q}$. The highest rate of LOH in DCIS approaches $50-80 \%$ and involves loci on chromosomes $16 \mathrm{q}, 17 \mathrm{p}$ and $17 \mathrm{q}$, suggesting that altered genes in these regions may play a role in the development of DCIS. In general, LOH frequency has been found to be higher in IDC than in DCIS (see notably Ando et al. 2000). Eighty per cent of the DCIS shared their LOH patterns with invasive carcinomas from the same breast, strongly supporting a precursor relationship between these lesions and the cancers they accompany (Deng et al. 1996).

Differences in $\mathrm{LOH}$ frequencies according to grade have been repeatedly observed in breast tumors. Thus, Ando et al. (2000) observed higher frequency of LOH at $16 \mathrm{q}$ in low- and intermediate-grade DCIS, while LOH at $11 \mathrm{p}$ and $17 \mathrm{p}$ were less frequent for these grades.

The fact that regions showing the highest levels of $\mathrm{LOH}$ were different in tumors of different grades has notably been illustrated by Shen et al. (2000). In their genome-wide search using laser capture micro-dissected tissue of breast carcinoma, these authors found $\mathrm{LOH}$ frequencies as follows:

Well-differentiated lesions: 16q22.1 (47.6\%), $16 \mathrm{q} 22.3$ $(42.1 \%), \quad 17 \mathrm{p} 12 \quad(37.5 \%), \quad 11 \mathrm{q} 22.1 \quad(35.0 \%), \quad 9 \mathrm{q} 22.33$ $(35.0 \%), \quad 1 \mathrm{q} 24.2 \quad(35.0 \%), \quad 12 \mathrm{p} 12.3 \quad(33.3 \%), \quad 3 \mathrm{p} 22.1$ $(33.3 \%), 1 \mathrm{q} 24.2(32.0 \%), 1 \mathrm{q} 44(31.6 \%)$.

Moderately differentiated lesions: 11q22.2. (42.9\%), $17 \mathrm{p} 12(42.1 \%), 14 \mathrm{q} 31.1 \quad(41.7 \%), 14 \mathrm{q} 32.11 \quad(41.2 \%)$, Xq13.3 (40.0\%), 16q22.1 (40.0\%), 14q24.1 (39.1\%), $8 \mathrm{p} 12(39.1 \%), 17 \mathrm{q} 21.31(37.0 \%), 16 \mathrm{q} 24.3(37.0 \%)$.

Poorly differentiated lesions: $17 \mathrm{p} 13.3$ (90.9\%), $17 \mathrm{p} 12$ (86.7\%), 17p13.3 (77.7\%), 17p13.2 (73.3\%), 4p15.1 $(73.3 \%), \quad 1 \mathrm{q} 32.1 \quad(71.4 \%), \quad 4 \mathrm{q} 28.2 \quad(70.0 \%), \quad 17 \mathrm{q} 21.31$ $(63.2 \%), \quad 3 \mathrm{q} 23 \quad(62.5 \%), \quad 1 \mathrm{p} 36.12 \quad(61.1 \%), \quad 22 \mathrm{q} 12.3$ (60.0\%), 8q24.3 (60.0\%), 3p14.3 (60.0\%).

Such results are in agreement with the observations of Ando et al. (2000) on 16q and 17p.

\section{Instability at the nucleotide level}

Genomic instability may also exist at the nucleotide level, resulting in base substitutions (nucleotide instability, or NIN) or in deletions or insertions of a few nucleotides (micro-satellite instability, or MIN). In breast tumors however, MIN has been observed only in a small subset $(<10 \%)$ of tumors (Ingvarsson 1999), and there is little 
evidence of mutation hotspots to support a significant etiological role of NIN in this type of cancer.

\section{Concluding remarks on karyotype and cytogenetic studies}

Breast cancer progression is accompanied by an increase in the number of genetic alterations. However, no specific gross alteration has been clearly and repeatedly associated with a specific tumor stage. In contrast, qualitative and quantitative differences exist between ER-positive and ER-negative tumors, as well as between low- and highgrade lesions. The lower occurrence of $16 \mathrm{q}$ loss in grade III cancers, repeatedly observed, appears to challenge the conception of tumor progression from ER-positive to ERnegative status and from low to high grade.

The data presented in this section concern major (high-frequency) DNA changes. Additional studies have demonstrated that a high genetic divergence characterizes $\mathrm{BCC}$ in vivo. A number of gains or losses of chromosomal material occur in tumors at a low frequency and at many different sites. This is in agreement with the concept of micro-heterogeneity in breast cancer. Multiple karyotypically related as well as unrelated clones (i.e. no single chromosomal abnormality is shared by them) have been found in a high proportion of carcinomas, suggesting that genetic mechanisms are crucially involved in the generation of small cell-to-cell and clone-to-clone variation in tumors (Aubele et al. 1999, Teixeira et al. 2002). Thus, invasive breast cancer may be viewed as a disease with multiple cytogenetic sub-clones and since no specific DNA alteration has been associated with invasion (see for instance Buerger et al. 2000b), it is concluded that complex patterns of non-specific changes are acquired during tumor progression. Accumulation of these minor (low-frequency) alterations distributed along the genome could ultimately overcome the mechanisms preventing cell aggressiveness. It has been found that the number of genomic aberrations is higher in tumors that give rise to recurrences (Dellas et al. 2002). Moreover, analysis of distant metastases (brain) showed that they were characterized by an accumulation of various genetic alterations and increased LOH frequency at all loci examined (Hampl et al. 1998-1999). In another study, the total number of aberrations detected by $\mathrm{CGH}$ exclusively in the lymph nodes or distant metastases was higher than in the primary breast tumors (2.5 vs 0.7) (Nishizaki et al. 1997). Analysis of single disseminated tumor cells has also revealed a high genetic heterogeneity, irrespective of whether they resided within the same compartment or within different homing sites, or whether they were isolated on repeated bone-marrow aspirations (Klein et al. 2002).

\section{Micro-array studies}

During recent years, gene expression studies have gained considerably from the introduction of massive and simultaneous analysis tools. Micro-array-mediated studies have allowed measuring the level of up to thousands of mRNAs in tumors (Sgroi et al. 1999, Bertucci et al. 2000, 2002, Perou et al. 2000, Ross et al. 2000, Finlin et al. 2001, Gruvberger et al. 2001, Ross \& Perou 2001, Sørlie et al. 2001, 2003, West et al. 2001, Zajchowski et al. 2001, Lacroix et al. 2002, van de Rijn et al. 2002, van't Veer et al. 2002, Ma et al. 2003, Sotiriou et al. 2003, Lacroix \& Leclercq 2004a). The existence of a few major phenotypes in breast cancer has been confirmed by such investigations.

Cluster analyses of micro-array data from series of breast tumors have repeatedly led to the identification of a major 'luminal epithelial-like/ER-positive' subtype, comprising $60-65 \%$ of tumors. It was characterized by the high expression of a gene set including ESR1 (the ERalpha itself) and genes either regulated by estrogens ( $L I V$ 1, TFF1, TFF3), or previously identified as co-expressed with ER ( $G A T A 3$, for instance). Other genes correlated to ESR1 expression were BCL2, COX6C, CRABP2, ERBB3, FBP1, HNF3A, HPN, IGFBP2, IGFBP5, MYB, NAT1, SELENBP1, VAV3 and XBP1 (Perou et al. 2000, Gruvberger et al. 2001, Ross \& Perou 2001, Sørlie et al. 2001, West et al. 2001, van't Veer et al. 2002, Lacroix \& Leclercq, 2004b; see also Table 3a). Besides the 'luminal epithelial-like/ER-positive' subtype, three subtypes characterized by low or no ESRl expression were found: a 'normal breast-like', grouping some tumors with samples of normal breast tissue; a 'basal/myoepithelial-like', comprising about $15-20 \%$ of tumors, and notably expressing high levels of keratins 5 (KRT5) and 17 (KRT17); an 'ERBB2+' group, characterized by the high level of expression of several genes in the ERBB2 amplicon at 17q22.24 including ERBB2, GRB7, MLN64 and others. Most tumors expressing a strong 'luminal epithelial-like/ER-positive' signature were of low grade, while the majority of tumors expressing mainly the other signatures were of high grade. Tumors expressing high levels of KRT5 and KRT17 (van de Rijn et al. 2002), or $E R B B 2$ were associated with poor clinical outcome.

Tumors expressing a basal/myoepithelial gene signature, based on micro-array studies, are expected to include the fraction of ductal carcinomas that are not pure myoepithelial cell carcinomas but that are of high grade, and for which a basaloid/myoepithelial cell differentiation and steroid receptor negativity has been demonstrated by IHC (see for instance Jones et al. 2001). Myoepithelial differentiation, high grade and ER negativity are also found in certain meta-plastic carcinomas (spindle-cell carcinomas and matrix-producing carcinomas), and in 
Table 3a A list of genes directly correlated to ESR1 expression in tumors, as determined by micro-array studies

\begin{tabular}{ll}
\hline Gene name & Gene product name(s) \\
\hline AR & Androgen receptor \\
BCL2 & B-cell CLL/lymphoma 2 \\
CCND1 & Cyclin D1 \\
CLDN7 & Claudin 7 \\
COX6C & Cytochrome c oxidase subunit VIc \\
CRABP2 & Cellular retinoic acid-binding protein 2 \\
CUTL1 & Cut-like 1, CCAAT displacement protein \\
ERBB3 & V-erb-b2 erythroblastic leukemia viral \\
& oncogene homolog 3 (avian) \\
ESR1 & Estrogen receptor-alpha \\
FBP1 & Fructose-1,6-bisphosphatase 1 \\
GATA3 & GATA sequence-binding protein 3 \\
HNF3A/FOXA1 & Hepatocyte nuclear factor 3A/Forkhead \\
& box A1 \\
HPN & Hepsin (transmembrane protease, serine 1) \\
IGF2 & Insulin-like growth factor 2 (somatomedin A) \\
IGFBP2 & Insulin-like growth factor-binding protein 2 \\
IGFBP5 & Insulin-like growth factor-binding protein 5 \\
LIV-1/SLC39A6 & Protein LIV-1/Solute carrier family 39 \\
& (metal ion transporter), member 6 \\
MYB & V-myb myeloblastosis viral oncogene \\
& homolog (avian) \\
NAT1 & N-acetyltransferase 1 (arylamine N-acetyl- \\
NPY1R & transferase) \\
SELENBP1 & Neuropeptide Y receptor Y1 \\
SLC9A3R1 & Selenium-binding protein 1 \\
STC2 & folute carrier family 9, isoform 3 regulatory \\
TFF1 & Stanniocalcin 2 \\
TIMP3 & Trefoil factor 1 (pS2, BCEI) \\
VAV3 & Vav 3 oncogene \\
XBP1 & \\
\hline &
\end{tabular}

invasive ductal carcinomas with large central acellular zones (Tsuda et al. 1999).

That ER status reflects major differences in tumor gene expression patterns and phenotypes was notably illustrated by Gruvberger et al. (2001) and West et al. (2001) who showed that the number of genes that discriminated tumors according to their ER status was high. Moreover, only a small proportion of these discriminator genes were known to be regulated by estrogens, suggesting that mechanisms underlying ESR1 gene expression are, indeed, common to many genes. Detailed analysis of the transcription of such genes could be valuable in understanding the molecular mechanisms underlying ESRI expression, which remain largely unclear. Among the genes positively correlated to ER were those correlated to ESRl expression in the 'luminal epithelial-like/ER-positive' phenotype (see above), but also $A R, C C N D 1, C U T L 1, I G F 2, N P Y 1 R$, SLC9A3R1, STC2 and TIMP3 (see Table 3a). Among those negatively correlated to ER were $C X 3 C L 1, C D H 3$,
Table 3b A list of genes inversely correlated to ESR1 expression in tumors, as determined by micro-array studies

\begin{tabular}{ll}
\hline Gene name & Gene product name(s) \\
\hline CDH3 & Cadherin 3, placental cadherin (P-cadherin) \\
CX3C1 & Chemokine (C-X3-C motif) receptor 1 \\
EGFR & Epidermal growth factor receptor \\
FABP7 & Fatty acid-binding protein 7, brain \\
GALNT3 & UDP-N-acetyl-alpha-D-galactosamine:polypeptide \\
& N-acetylgalactosaminyltransferase 3 (GalNAc-T3) \\
GSTP1 & Glutathione S-transferase pi \\
HMGIY & High-mobility group protein isoforms I and Y \\
KRT7 & Keratin 7 \\
LAD1 & Ladinin 1 \\
LCN2 & Lipocalin 2 (oncogene 24p3) \\
S100A8 & S100 calcium-binding protein A8 (calgranulin A) \\
S100A9 & S100 calcium-binding protein A9 (calgranulin B) \\
SERPINB5 & Serine (or cysteine) proteinase inhibitor, clade \\
& B (ovalbumin), member 5 \\
SLPI & Secretory leukocyte protease inhibitor (antileuko- \\
SOD3 & proteinase) \\
& Superoxide dismutase 3, extracellular
\end{tabular}

EGFR, FABP7, GALNT3, GSTP1, HMGIY, KRT7, LAD1, LCN2, S100A8, S100A9, SERPINB5, SLPI and SOD3 (see also Table $3 \mathrm{~b}$ ).

According to micro-array studies, only a few distinct breast tumor classes seem to exist. This suggests that phenotype transition from one class (for instance the 'luminal epithelial-like/ER-positive') to another is unlikely to occur in the same tumor during progression. Tumor phenotypes seem to be defined very early in the development of the lesions. This is further supported by micro-array-mediated analysis of invasion.

Micro-array investigations have also aimed to define the genes, if any, contributing to the invasive phenotype of breast tumors. However, in a study of 36 ductal tumors, extensive similarities at the transcriptome level were found among the distinct stages of progression (atypical hyperplasia, carcinoma in situ, invasive carcinoma), supporting the hypothesis that alterations that confer on tumors their potential for invasive growth are already present in the pre-invasive stages. Contrasting with stage, different tumor grades were associated with distinct gene expression signatures, suggesting that tumor grade is unlikely to change significantly during progression. A few genes were found to have an increased expression both in high tumor grade and in the carcinoma in situ/invasive carcinoma transition. They included genes involved in the cell cycle, centrosomal function and DNA repair (Ma et al. 2003).

In another study, comparison of gene expression changes between cancer cells at the periphery and in the center of breast cancers was performed using a combination of micro-dissection and micro-array analysis 
(Zhu et al. 2003). Of 1176 genes analyzed, only 22 changed their expression levels in the periphery relative to the central region: 15 were up-regulated (including VIM and $A H R C$, encoding the small GTPase RhoC) and 7 were down-regulated (including TSG101) (arbitrary threshold of 1.5 -fold or greater). RhoC has already been found to have increased expression in more motile, invasive and metastatic tumors, and in the most lethal form of the locally advanced breast cancer, inflammatory breast cancer (Kleer et al. 2002). VIM up-regulation might indicate the initiation of epithelial-mesenchymal conversion at the periphery. TSG101 has been previously proposed as a tumor suppressor gene, but it seems that its expression could rather be needed for activities associated with aspects of tumor progression (Wagner et al. 2003, Zhu et al. 2004). Whether the expression of these genes was altered under the influence of normal surrounding tissue is presently unknown.

While a few changes in gene expression and, possibly, phenotype at the invasive front of tumors are suggested by the previous example, various micro-array studies indicate that the ability of BCC to metastasize to distant sites could indeed be an early and inherent genetic property. For instance, a 70-gene expression signature was found to be a strong independent factor in predicting a short interval to distant metastases. Those breast cancer patients presenting with a good prognostic fingerprint had a $95 \%$ chance of surviving the next decade, whereas those with a bad fingerprint had only a $55 \%$ chance of surviving (van de Vijver et al. 2002, van't Veer et al. 2002).

Other investigators identified aggregate patterns of gene expression (called 'meta-genes') allowing the classification of breast tumors by their likelihood of having associated LN metastases at diagnosis and by 3-year recurrence risk (Huang et al. 2003).

Bone marrow (BM) is a common homing organ for metastatic BCCs. Micro-array analysis of 83 breast tumor samples showed distinct profiles between BM-positive $(n=23)$ and BM-negative $(n=60)$ lesions. Nine genes were up-regulated while 77 were down-regulated in BMpositive tumors. In the same study, the expression profile associated with lymphatic metastasis was also studied. Forty-four genes were found to distinguish between LNpositive and LN-negative lesions. Again, the number of up-regulated genes in LN-positive tumors was smaller $(n=9)$ than the number of down-regulated genes $(n=35)$, suggesting that transcriptional repression of genes is important for metastasis. Of interest, the gene signature associated with LN metastasis was distinct from the signature associated with BM micro-metastasis, with only nine genes in common, suggesting that the two routes of dissemination could be governed by different molecular determinants (Woelfle et al. 2003)
There are studies suggesting that metastatic signatures could be common to cancers of various origins. Thus, a 17-gene expression signature that distinguished primary from metastatic adenocarcinomas was found from lung, breast, prostate, colorectal, uterus and ovary cancers. It was applied to 279 primary solid tumors (lung, breast, prostate, lymphoma and medulloblastoma). Those tumors carrying the gene expression signature were most likely to be associated with metastasis and poor clinical outcome $(P<0.03)$ (Ramaswamy et al. 2003).

All this suggests that the clinical outcome of individuals with cancer can be predicted using the gene expression profiles of primary tumors at diagnosis. It is proposed that some tumors could be pre-ordained to spread, while some would have a favorable combination of initiating events making them less likely to disseminate. The existence of early-expressed metastatic signatures is a further argument against the widely accepted idea that metastatic potential is acquired relatively late during multi-step tumorigenesis. It supposes that not just a few rare cells in the tumor acquire metastatic ability, but that all cells within such tumors have this ability to metastasize. It must be mentioned, however, that the metastatic signatures found by different groups have only a few, if any, genes in common, raising some questions about their potential use as clinical tools.

\section{Concluding remarks on micro-array studies}

Based on their pattern of gene expression, it appears that breast tumors may be grouped in a limited number of distinct classes largely correlated to ER status and grade. A transition of tumors from one to another of these classes seems unlikely, considering the number of differences in gene expression that discriminate them. Moreover, no 'mixed class' has been observed. Microarray data also suggest that a (very) few genes could be susceptible to allowing distinction between in situ and invasive breast tumors. Other genes, such as ERBB2, KRT5 and KRT17, seem to be associated with higher aggressiveness.

\section{Epigenetic alterations}

Epigenetic alterations are heritable modifications of gene expression that do not involve mutation. They include hypermethylation of $\mathrm{CpG}$ island-rich promoters, which contributes to the transcriptional inactivation of a number of tumor-related genes in many types of cancer (Malik \& Brown 2000, Widschwendter \& Jones 2002). A series of genes frequently hypermethylated in breast cancers are listed in Table 4. The heritability of methylation states and the secondary nature of the decision to attract or exclude methylation suggest that DNA methylation is adapted for the cellular memory 
Table $4 \mathrm{~A}$ list of genes for which $\mathrm{CpG}$ island promoter hypermethylation has been demonstrated in tumors

\begin{tabular}{|c|c|}
\hline Gene name & Gene product name(s) \\
\hline$A P C$ & Adenomatosis polyposis coli \\
\hline$A R H I$ & Ras homolog gene family, member I \\
\hline$A S C$ & $\begin{array}{l}\text { Apoptosis-associated speck-like protein } \\
\text { containing a CARD }\end{array}$ \\
\hline$B R C A 1$ & Breast cancer 1 , early onset \\
\hline CCND2 & Cyclin D2 \\
\hline $\mathrm{CDH1}$ & Cadherin 1 , epithelial cadherin (E-cadherin) \\
\hline $\mathrm{CDH} 13$ & Cadherin $13, \mathrm{H}$-cadherin (heart) \\
\hline CDKN2A & Cyclin-dependent kinase inhibitor 2A ( $p 16)$ \\
\hline$D A P K 1$ & Death-associated protein kinase 1 \\
\hline ESR1 & Estrogen receptor-alpha \\
\hline$F A B P 3$ & Fatty acid-binding protein 3 (MDGI) \\
\hline FHIT & Fragile histidine triad gene \\
\hline GJB2 & $\begin{array}{l}\text { Gap junction protein, beta 2, 26kD } \\
\text { (connexin 26) }\end{array}$ \\
\hline GPC3 & Glypican 3 \\
\hline$G S N$ & Gelsolin (amyloidosis, Finnish type) \\
\hline GSTP1 & Glutathione S-transferase pi \\
\hline HIC1 & Hypermethylated in cancer 1 \\
\hline HOXA5 & Homeo box A5 \\
\hline HSHIN1 & High in normal-1 \\
\hline IL6 & Interleukin-6 \\
\hline$K L K 10$ & Kallikrein 10 \\
\hline MGMT & Methylguanine-DNA methyltransferase \\
\hline NME1 & $\begin{array}{l}\text { Protein expressed in non-metastatic } \\
\text { cells } 1(\mathrm{~nm} 23 \mathrm{~A})\end{array}$ \\
\hline$P G R$ & Progesterone receptor \\
\hline PLAU & Plasminogen activator, urokinase \\
\hline PRDM2(1) & $\begin{array}{l}\text { PR domain-containing protein } 2 \text { (RIZ1), } \\
\text { transcript } 1\end{array}$ \\
\hline$P R K C D B P$ & $\begin{array}{l}\text { Protein kinase } \mathrm{C} \text {, delta-binding protein } \\
\text { (SRBC) }\end{array}$ \\
\hline PRSS8 & Protease, serine, 8 (prostasin) \\
\hline$R A R B(2)$ & Retinoic acid receptor, beta (transcript 2) \\
\hline $\operatorname{RASSF1}(A)$ & $\begin{array}{l}\text { Ras association (RalGDS/AF-6) domain } \\
\text { family } 1 \text { (transcript A) }\end{array}$ \\
\hline SERPINB5 & $\begin{array}{l}\text { Serine (or cysteine) proteinase inhibitor, } \\
\text { clade B (ovalbumin), member } 5\end{array}$ \\
\hline SFN & Stratifin \\
\hline SLC19A1 & $\begin{array}{l}\text { Solute carrier family } 19 \text { (folate transporter), } \\
\text { member } 1\end{array}$ \\
\hline SNCG & $\begin{array}{l}\text { Synuclein, gamma (breast cancer-specific } \\
\text { protein 1) }\end{array}$ \\
\hline SYK & Spleen tyrosine kinase \\
\hline TFF1 & Trefoil factor 1 (pS2, BCEI) \\
\hline TIMP3 & Tissue inhibitor of metalloproteinase 3 \\
\hline WT1 & Wilms tumor 1 \\
\hline
\end{tabular}

For references, see Widschwendter et al. 2002, Paz et al. 2003.

(Bird 2002). Hypermethylation could participate in the development and the preservation of specific cell phenotypes, by definitely 'bolting' specific sets of genes.

Few studies have examined potential correlations between promoter hypermethylation and tumor stage or grade. However, in a laser capture micro-dissectionassisted analysis of 16 specimens with intraductal and invasively growing breast cancer, promoter hypermethylation of CDKN2A (p16), SFN (stratifin), RASSF1A and $C C N D 2$ (cyclin D2) was found to be largely conserved between both compartments. This suggests that in most cases the epigenetic inactivation takes place before invasive growth develops (Lehmann et al. 2002). A number of hypermethylated genes are associated with the distinctive phenotypes observed in tumors. For instance, ESRI, PGR, $C D H 1, T F F 1$ etc. are associated with the ER-positive/lowgrade phenotype. In contrast, CDKN2A, GSTPI, PLAU etc. are preferentially found in ER-negative/high-grade tumors. The fact that the expression of many genes for which promoter methylation has been shown is correlated to the ER status was demonstrated by Yan et al. (1999). These authors performed a methylation profile analysis of $7776 \mathrm{CpG}$ islands, which led to the identification of $\mathrm{CpG}$ island clusters that can significantly distinguish $\mathrm{ER}-/ \mathrm{PR}-$ from $\mathrm{ER}+/ \mathrm{PR}+$ breast tumors. Thus, epigenetic events might significantly contribute to stabilize the phenotype of tumors. As we have concluded that the BCC phenotype is unlikely to change significantly during progression, we conclude that hypermethylation is not expected to play a key role in this progression.

\section{Conclusion on genetic/epigenetic studies}

(Epi)genetic studies have not revealed major changes in the gross DNA alterations or in the gene expression patterns of breast tumors during progression. Tumor progression to invasiveness and metastasis probably results from the accumulation by in situ carcinoma of various minor and localized genetic or epigenetic events. This would eventually alter the molecular balances controlling cell adhesion, migratory ability, proteolysis and/or angiogenesis. Such evolution is suggested by the known micro-heterogeneity of tumor tissues.

\section{Tumor size and progression}

Pre-invasive cells express almost all of the features associated with a full-blown cancer phenotype: sustained cell proliferation, disregard of growth and differentiation controlling signals, evasion of apoptosis, immortalization and induction of angiogenesis. However, they (apparently) lack the ability to invade surrounding tissue. How is this property acquired?

Tumor size may play a role in the acquisition of invasiveness. In fact, and with the possible exception of BRCA1-associated tumors (Foulkes 2004), a relation has been repeatedly found between tumor size, on the one hand, and LN status and reduced survival, on the other hand (see for instance Carter et al. 1989, Hayes et al. 2002). 
When growing, a tumor accumulates genetic alterations (see for instance Sato et al. 1991). This may allow the emergence of different cell sub-populations sharing essentially the same 'portrait', but exhibiting minor phenotype differences. One may speculate that a local complex cooperation between these sub-populations might favor invasion. A growing in situ tumor is also believed to exert a mechanical stress on its neighboring basement membrane. Moreover, BCC accumulation in a confined space might lead to local concentrations of various secreted molecules (for instance metalloproteinases (MMPs)) high enough to overcome the mechanical and molecular resistance expressed (for instance through secretion of MMP inhibitors) by the surrounding normal cells.

\section{Interactions between tumor cells and their cellular environment}

It is now widely accepted that tumor evolution is highly dependent on interactions (by direct contact or through paracrine signaling) between BCCs and other cell types present in their vicinity. BCCs modulate stromal cell activity. In turn, the stromal micro-environment profoundly influences many steps of tumor progression. In various experimental tumor models, the micro-environment affects the efficiency of tumor formation, the rate of tumor growth, the onset of angiogenesis, the extent of invasiveness and the ability of tumor cells to metastasize (Elenbaas \& Weinberg 2001). Among the cell types with which BCCs may interact are normal breast epithelial cells, blood cells, vascular endothelial cells and, at metastatic sites, specialized cells from brain, lung, liver, bone, bone marrow etc. (Lacroix et al. 1996, 2000, Sierra et al. 1997, Siwek et al. 1997, Dano et al. 1999, Yoneda 2000, Moore 2001, Deugnier et al. 2002, Toillon et al. 2002a,b, Ben-Hur et al. 2002, Blot et al. 2003). Among others, myoepithelial cells and stromal fibroblasts are thought to be implicated in the first steps of invasion.

Myoepithelial cells have been seen as "natural tumor suppressors' (Deugnier et al. 2002, Barsky 2003). Surrounding the mammary ducts, they deposit extra-cellular matrix components, express high amounts of several proteinase inhibitors and appear responsive for limiting invasive behavior. The loss of this cell type, observed only in invasive tumors, should permit subsequent invasion and tumor progression (Sternlicht et al. 1997, Xiao et al. 1999, Barsky 2003). However, the mechanisms by which BCCs may reduce the amount of myoepithelial cells in their neighborhood remain largely unknown.

BCCs also have paracrine interactions with their surrounding stromal fibroblasts. In tumors, these latter are often phenotypically different from normal fibroblasts. For example, they may express smooth muscle differentiation with increased motility into collagen gel 'myofibroblasts' (Wang \& Tetu 2002). Myofibroblasts, which comprise a predominant stromal cell type in breast tumors, are often seen in close association with the myoepithelium surrounding carcinoma in situ. Under the influence of BCCs, stromal (myo)fibroblasts can increase their production of various components of the urokinase (uPA) system (Schnack Nielsen et al. 2002) and of MMPs (Heppner et al. 1996). Since BCCs themselves are able to produce proteolysis-related molecules (uPA, uPAR, PAI1, MMPs, matriptase/ST14) (Oberst et al. 2001), this is could lead to a considerable local matrix degradation and cancer progression (Dano et al. 1999).

\section{Lobular breast cancer}

Lobular tumors represent a minority (5-10\%) of all breast carcinomas, but their occurrence appears to have increased steadily and disproportionately in recent years, possibly in association with increased use of combined hormone replacement therapy (Li et al. 2003a, Verkooijen et al. 2003). Compared with the ductal type, the characteristics of lobular tumors and the mechanisms of their progression have been less investigated. While additional studies will be necessary to draw firm conclusions, current data on lobular cancer will be summarized here.

Lobular tumors are usually composed of small monomorphic round cells, without significant nuclear atypia or abundant cytoplasm. Cells are most often arranged in single files. When present, invasion typically occurs in a manner that does not destroy anatomic structures or excite a substantial connective tissue response. Cells infiltrate alone or in files. Targetoid arrangements around non-neoplastic ducts may be observed. Besides the usual type, several variants have been described (signet-ring, alveolar, solid and others). The most studied of these, the pleomorphic variant, is characterized by a marked nuclear enlargement and pleomorphism, and small nuclei. It has moderate to high nuclear grade, contrasting with the low grade found in the usual type (Weidner \& Semple 1992, Frykberg 1999, Soslow et al. 2000). In addition, lobular cancer may occasionally be observed in association with low-grade ductal cancer.

According to a series of data on proliferation, biology and genetics, lobular tumors in general appear to exhibit many similarities with low-grade tumors, but few with high-grade ductal tumors. Among lobular tumors, the usual type expresses a more well-differentiated and a lessproliferative phenotype than the pleomorphic type.

For instance, proliferation and apoptotic indexes were shown to be higher in ductal (in general) than in lobular cancers. These indexes were higher in pleomorphic than in 
the usual lobular tumors (Kruger et al. 1999, Frolik et al. 2001, Arpino et al. 2004).

As also frequently observed in the low-grade ductal type: (1) the great majority of in situ and invasive lobular tumors express significant levels of ER, PR, BCL2, TFF1 and TFF3; (2) they are rarely ERBB2- and P53-positive, and their vimentin, VEGF and EGFR levels are low or null (Domagala et al. 1990, Poulsom et al. 1997, Lee et al. 1998, Frolik et al. 2001, Rosenthal et al. 2002, Arpino et al. 2004). The most noticeable feature distinguishing lobular and (low-grade) ductal tumors is the absence of E-cadherin expression in the former (Berx et al. 1996, Vos et al. 1997, Lehr et al. 2000, Goldstein et al. 2001, Wahed et al. 2002). In two independent gene expression studies comparing ductal and lobular carcinomas, the sole common discriminator identified was $C D H 1$, which was significantly down-regulated in lobular samples (Korkola et al. 2003, Zhao et al. 2004). While marker expression is essentially similar in the usual lobular cancer and its variants (Soslow et al. 2000), the pleomorphic type has been found to have less ER and PR, and more P53 positivity than the usual type (Radhi 2000).

Using $\mathrm{CGH}$, a higher number of genetic alterations has been observed in invasive, as compared with in situ lobular tumors. On the other hand, a frequent concomitant 1q gain and 16q loss appears to occur in both ductal and (in situ and invasive) lobular carcinomas. This has been associated with ER and PR presence and low proliferation (Etzell et al. 2001, Rennstam et al. 2003, Farabegoli et al. 2004). In lobular cancers, the most frequent losses are found at $16 \mathrm{q}$ followed by $17 \mathrm{p}$, as also observed by $\mathrm{LOH}$ studies in well-differentiated ductal cancers (see above and in Shen et al. 2000).

Most studies, including many of those cited above, have indicated that when invasive and in situ components are present in lobular tumors, both are of the same type (usual, pleomorphic etc.) (see also Sneige et al. 2002) and are very similar, based on their expression of biological markers and their pattern of genetic alterations. For instance, a frequent hypermethylation of the five cancerrelated genes RASSF1A, HIN1, RARB, CCND2 and TWIST, has been observed in in situ as well as in invasive lobular cancers (Fackler et al. 2003).

A major difference between lobular and ductal tumors is their associated pattern of metastasis. Lobular carcinomas frequently metastasize to ovary, gastrointestinal tract, peritoneum and bone marrow; they less frequently colonize the lungs and the central nervous system (Borst \& Ingold 1993, Arpino et al. 2004, Ferlicot et al. 2004). This difference could be essentially due to the lack of $C D H 1$ expression in lobular cancer, as compared with the ductal type (see above). In the absence of this adhesion molecule, the permeation of cancer cells through tissues could be facilitated (Goldstein 2002). It has been shown that $\mathrm{CDH1}$ expression may favor the appearance of intralymphatic tumor emboli, which are rarely observed in lobular cancer (Gupta et al. 2003). In addition to the specific metastatic pattern, the absence of CDH1 could also explain most of the peculiar cytological aspects of lobular cancer cells.

In summary, numerous features of lobular tumors, especially when they are of the usual type, are also observed in low-grade ductal tumors. No major difference seems to be associated with the progression of this type of cancer.

\section{The origin of tumors - breast cancer stem cells}

Breast tumors may exhibit different 'portraits' that are essentially maintained during progression from in situ to metastasis. On the other hand, it is now widely admitted that most tumors are clonal and represent the progeny of a single cell. Therefore, it may be asked whether the distinct tumor phenotypes are already present in the original tumor-initiating cells, or if phenotype divergence occurs at a later stage of tumor evolution from a common precursor.

Various studies on normal mammary tissue have identified a population of supra-basal cells that are able to generate both themselves and differentiated luminal epithelial and myoepithelial cells. These stem cells have a long life and a large replicating potential, making them good candidates for the cells of origin of cancer (Stingl et al. 2001, Boecker \& Buerger 2003, Clarke et al. 2003, Dontu et al. 2003, Petersen et al. 2003, Smalley \& Ashworth 2003).

Observations have long suggested that not all transformed cells composing a breast tumor are able to regenerate the tumor upon transplantation. The existence of 'breast cancer stem cells' (BCSCs) has recently gained more credibility through an elegant series of experiments by Al-Hajj et al. (2003). These authors identified in several tumors a sub-population of cluster of differentiation (CD)44+ CD24-/low epithelial-specific antigen (ESA)+ cells, of which as few as 200/1000 were consistently able to form tumors in mice. In contrast, 20000 cells from other sub-populations were unable to do so. CD44 is a marker of basal/myoepithelial cells. CD24 and ESA are found in luminal epithelial cells. Thus, BCSCs express some (but not all) markers representative of both phenotypes, and it is conceivable that the progeny of these cells could evolve, probably rapidly, towards only one of these phenotypes. The final phenotype could result from specific events. For instance, tumors induced in transgenic mice by components of the WNT1 signaling pathway (wnt-1, beta-catenin, c-myc) were found to contain both luminal epithelial and 
myoepithelial tumor cells; in contrast, no myoepithelial tumor cells were observed in tumors induced by ERBB2 (Rosner et al. 2002, Li et al. 2003b). Most BRCA1associated breast tumors have a basal-like 'portrait'. To explain this, it has been hypothesized that an intact BRCA1 is needed to allow breast cells to acquire a luminal epithelial phenotype (Foulkes et al. 2003). Cells in which BRCA1 is truncated would be committed to a basal-like lineage.

The existence of 'monophenotypic' self-renewing BCSCs from which distinct tumor 'portraits' could be obtained may have important therapeutic implications. For instance, ER-positive tumors could indeed be composed of a bulk of ER-expressing cells associated with a very few BCSCs. In such a case, anti-estrogenbased therapy would be efficient only on ER-positive cells, allowing BCSCs to later reconstitute the tumor. New therapeutic targets should be identified that could be exploited to eliminate BCSCs from patients.

On the other hand, the increasing evidence that tumors maintain most of their 'portrait' during progression should also have consequences on their treatment. Different phenotypes mean different expression patterns of various drug targets, or modulators of drug action: components of estrogen metabolic pathways, proteinases, transporter proteins etc. The efficacy of strategies developed against such molecules is expected to be largely predictible from the most precise determination of the tumor phenotype.

\section{General conclusions}

Many attempts have been and are still being made to identify critical events responsible for the development and progression of breast cancer. In spite of this, the mechanisms underlying notably tumor invasion and BCC dissemination remain largely unclear. One of the current progression models for ductal tumors proposes that carcinoma in situ may evolve into invasive ductal carcinoma and subsequently produce metastases through an accumulation of molecular abnormalities possibly allowing extensive phenotype changes and gain of aggressiveness. To describe this progression, the 'clonal hypothesis' has generally been well received in the breast cancer community.

However, the data presented here indicate that most breast carcinomas cannot be viewed as a collection of a few successive clonal populations being associated with the major stages of progression. Rather unexpectedly, in situ and invasive components of carcinomas appear very similar, and this similarity has also been repeatedly observed in metastases, regardless of their localization, and in recurrences. In fact, at any step of their progression, breast tumors may be rather considered as collections of cell sub-populations exhibiting the same general pattern of gross recurrent genetic alterations and sharing the same major phenotypic features. Regarding phenotype, a few major 'portraits' may be identified. Tumors characterized by expression of ER and a series of correlated markers are generally associated with low proliferation/apoptosis indexes and a low grade (welldifferentiated, luminal epithelial phenotype). Tumors characterized by the lack (or very low amounts) of ER are generally associated with high proliferation/apoptosis indexes and a basal-like, poorly differentiated aspect.

Although the tumor phenotype remains essentially stable, genetic alterations accumulate during progression. Micro-heterogeneity exists, due to minor (low-frequency) DNA changes, generally restricted to small sub-populations of BCCs. This could result in minor phenotype differences. Invasion could proceed from a local complex co-operation between different sub-populations. Moreover, dialogue between tumor cells and their surrounding normal cells could also play an important role in the establishment of biological conditions propitious to cell dissemination.

There are also data, obtained notably from microarray studies, suggesting that breast tumors do not really progress, as they could possess very early the ability to invade and metastasize. According to such a view, the distinction between in situ and invasive carcinoma would not reflect a significant difference in the properties of BCCs. To reach definite conclusions on the most pertinent model, future investigations should exploit the most recent analysis techniques (including micro-dissection) to examine genotype and phenotype of individual BCCs close to the invasion front and in invaded tissues.

\section{Acknowledgements}

This work was supported by grants from the 'Recherche d'initiatives' program (Région WallonneWalloon Region) and the 'Fonds Jean-Claude Heuson'. ML is supported by grants from Eppendorf Array Technologies (EAT, Namur, Belgium) and from European Communities (BreastMed Consortium, INCO MED ICA3-CT-2002-1005). There is no conflict of interest that would prejudice the impartiality of this article.

\section{References}

Adeyinka A, Mertens F, Idvall I, Bondeson L, Ingvar C, Mitelman F \& Pandis N 1999 Different patterns of chromosomal imbalances in metastasising and nonmetastasising primary breast carcinomas. International Journal of Cancer 84 370-375. 
Al-Hajj M, Wicha MS, Benito-Hernandez A, Morrison SJ \& Clarke MF 2003 Prospective identification of tumorigenic breast cancer cells. PNAS 100 3983-3989.

Ando Y, Iwase H, Ichihara S, Toyoshima S, Nakamura T, Yamashita H, Toyama T, Omoto Y, Karamatsu S, Mitsuyama S, Fujii Y \& Kobayashi S 2000 Loss of heterozygosity and microsatellite instability in ductal carcinoma in situ of the breast. Cancer Letters 156 207-214.

Ardini E, Agresti R, Tagliabue E, Greco M, Aiello P, Yang LT, Menard S \& Sap J 2000 Expression of protein tyrosine phosphatase alpha (RPTPalpha) in human breast cancer correlates with low tumor grade, and inhibits tumor cell growth in vitro and in vivo. Oncogene 19 4979-4987.

Arpino G, Bardou VJ, Clark GM \& Elledge RM 2004 Infiltrating lobular carcinoma of the breast: tumor characteristics and clinical outcome. Breast Cancer Research 6 R149-R156.

Aubele MM, Cummings MC, Mattis AE, Zitzelsberger HF, Walch AK, Kremer M, Hofler H \& Werner M 2000 Accumulation of chromosomal imbalances from intraductal proliferative lesions to adjacent in situ and invasive ductal breast cancer. Diagnostic Molecular Pathology 9 14-19.

Aubele M, Werner M \& Hofler H 2002 Genetic alterations in presumptive precursor lesions of breast carcinomas. Analytical Cell Pathology 24 69-76.

Barbareschi M 1999 p27 Expression, a cyclin dependent kinase inhibitor in breast carcinoma. Advances in Clinical Pathology 3 119-127.

Barbareschi M, van Tinteren H, Mauri FA, Veronese S, Peterse H, Maisonneuve P, Caffo O, Scaioli M, Doglioni C, Galligioni E, Dalla Palma P \& Michalides R 2000 p27(kip1) expression in breast carcinomas: an immunohistochemical study on 512 patients with long-term follow-up. International Journal of Cancer 89 236-241.

Barbareschi M, Maisonneuve P, Aldovini D, Cangi MG, Pecciarini L, Angelo Mauri F, Veronese S, Caffo O, Lucenti A, Palma PD, Galligioni E \& Doglioni C 2003 High syndecan-1 expression in breast carcinoma is related to an aggressive phenotype and to poorer prognosis. Cancer $\mathbf{9 8}$ 474-483.

Barnes DM \& Gillett CE 1998 Cyclin D1 in breast cancer. Breast Cancer Research and Treatment 52 1-15.

Barnes DM, Lammie GA, Millis RR, Gullick WL, Allen DS \& Altman DG 1988 An immunohistochemical evaluation of cerbB-2 expression in human breast carcinoma. British Journal of Cancer 58 448-452.

Barsky SH 2003 Myoepithelial mRNA expression profiling reveals a common tumor-suppressor phenotype. Experimental and Molecular Pathology 74 113-122.

Ben-Hur H, Cohen O, Schneider D, Gurevich P, Halperin R, Bala U, Mozes M \& Zusman I 2002 The role of lymphocytes and macrophages in human breast tumorigenesis: an immunohistochemical and morphometric study. Anticancer Research 22 1231-1238.

Bertucci F, Houlgatte R, Benziane A, Granjeaud S, Adelaide J, Tagett R, Loriod B, Jacquemier J, Viens P, Jordan B, Birnbaum D \& Nguyen C 2000 Gene expression profiling of primary breast carcinomas using arrays of candidate genes. Human Molecular Genetics 9 2981-2991.
Bertucci F, Nasser V, Granjeaud S, Eisinger F, Adelaide J, Tagett R, Loriod B, Giaconia A, Benziane A, Devilard E, Jacquemier J, Viens P, Nguyen C, Birnbaum D \& Houlgatte R 2002 Gene expression profiles of poor-prognosis primary breast cancer correlate with survival. Human Molecular Genetics 11 863-872.

Berx G, Cleton-Jansen AM, Strumane K, de Leeuw WJ, Nollet F, van Roy F \& Cornelisse C 1996 E-cadherin is inactivated in a majority of invasive human lobular breast cancers by truncation mutations throughout its extracellular domain. Oncogene 13 1919-1925.

Beviglia L, Matsumoto K, Lin CS, Ziober BL \& Kramer RH 1997 Expression of the c-Met/HGF receptor in human breast carcinoma: correlation with tumor progression. International Journal of Cancer 74 301-309.

Bieche I, Onody P, Tozlu S, Driouch K, Vidaud M \& Lidereau R 2003 Prognostic value of ERBB family mRNA expression in breast carcinomas. International Journal of Cancer 106 758-765.

Bijker N, Peterse JL, Duchateau L, Robanus-Maandag EC, Bosch CA, Duval C, Pilotti S \& van de Vijver MJ 2001 Histological type and marker expression of the primary tumor compared with its local recurrence after breast-conserving therapy for ductal carcinoma in situ. British Journal of Cancer 84 539-544.

Binder C, Marx D, Overhoff R, Binder L, Schauer A \& Hiddemann W 1995 Bcl-2 protein expression in breast cancer in relation to established prognostic factors and other clinicopathological variables. Annals of Oncology 6 1005-1010.

Bird A 2002 DNA methylation patterns and epigenetic memory. Genes and Development 16 6-21.

Blanco MJ, Moreno-Bueno G, Sarrio D, Locascio A, Cano A, Palacios J \& Nieto MA 2002 Correlation of Snail expression with histological grade and lymph node status in breast carcinomas. Oncogene 21 3241-3246.

Blot E, Chen W, Vasse M, Paysant J, Denoyelle C, Pille JY, Vincent L, Vannier JP, Soria J \& Soria C 2003 Cooperation between monocytes and breast cancer cells promotes factors involved in cancer aggressiveness. British Journal of Cancer $\mathbf{8 8}$ 1207-1212.

Boecker W \& Buerger H 2003 Evidence of progenitor cells of glandular and myoepithelial cell lineages in the human adult female breast epithelium: a new progenitor (adult stem) cell concept. Cell Proliferation 36 73-84.

Boecker W, Buerger H, Schmitz K, Ellis IA, van Diest PJ, Sinn HP, Geradts J, Diallo R, Poremba C \& Herbst H 2001 Ductal epithelial proliferations of the breast: a biological continuum? Comparative genomic hybridization and high-molecularweight cytokeratin expression patterns. Journal of Pathology 195 415-421.

Borst MJ \& Ingold JA 1993 Metastatic patterns of invasive lobular versus invasive ductal carcinoma of the breast. Surgery 114 637-641.

Bouras T, Southey MC, Chang AC, Reddel RR, Willhite D, Glynne R, Henderson MA, Armes JE \& Venter DJ 2002 Stanniocalcin 2 is an estrogen-responsive gene coexpressed with the estrogen receptor in human breast cancer. Cancer Research 62 1289-1295. 
Boyer B, Valles AM \& Edme N 2000 Induction and regulation of epithelial-mesenchymal transitions. Biochemical Pharmacology 60 1091-1099.

Briffod M, Hacene K \& Le Doussal V 2000 Immunohistochemistry on cell blocks from fine-needle cytopunctures of primary breast carcinomas and lymph node metastases. Modern Pathology 13 841-850.

Buerger H, Mommers EC, Littmann R, Diallo R, Brinkschmidt C, Poremba C, Dockhorn-Dworniczak B, van Diest PJ \& Bocker W 2000a Correlation of morphologic and cytogenetic parameters of genetic instability with chromosomal alterations in in situ carcinomas of the breast. American Journal of Clinical Pathology 114 854-859.

Buerger H, Simon R, Schafer KL, Diallo R, Littmann R, Poremba C, van Diest PJ, Dockhorn-Dworniczak B \& Bocker W $2000 b$ Genetic relation of lobular carcinoma in situ, ductal carcinoma in situ, and associated invasive carcinoma of the breast. Molecular Pathology 53 118-121.

Callagy G, Cattaneo E, Daigo Y, Happerfield L, Bobrow LG, Pharoah PD \& Caldas C 2003 Molecular classification of breast carcinomas using tissue microarrays. Diagnostic Molecular Pathology 12 27-34.

Camp RL, Charette LA \& Rimm DL 2000 Validation of tissue microarray technology in breast carcinoma. Laboratory Investigations 80 1943-1949.

Carmeci C, Thompson DA, Kuang WW, Lightdale N, Furthmayr H \& Weigel RJ 1998 Moesin expression is associated with the estrogen receptor-negative breast cancer phenotype. Surgery 124 211-217.

Carter CL, Allen C \& Henson DE 1989 Relation of tumor size, lymph node status, and survival in 24,740 breast cancer cases. Cancer 63 181-187.

Cingoz S, Altungoz O, Canda T, Saydam S, Aksakoglu G \& Sakizli M 2003 DNA copy number changes detected by comparative genomic hybridization and their association with clinicopathologic parameters in breast tumors. Cancer Genetics and Cytogenetics 145 108-114.

Clarke RB, Anderson E, Howell A \& Potten CS 2003 Regulation of human breast epithelial stem cells. Cell Proliferation $\mathbf{3 6}$ $45-58$.

Cserni G 2002 Tumor histological grade may progress between primary and recurrent invasive mammary carcinoma. Journal of Clinical Pathology 55 293-297.

Curmi PA, Nogues C, Lachkar S, Carelle N, Gonthier MP, Sobel A, Lidereau R \& Bieche I 2000 Overexpression of stathmin in breast carcinomas points to highly proliferative tumors. British Journal of Cancer 82 142-150.

Dandachi N, Hauser-Kronberger C, More E, Wiesener B, Hacker GW, Dietze O \& Wirl G 2001 Co-expression of tenascin-C and vimentin in human breast cancer cells indicates phenotypic transdifferentiation during tumor progression: correlation with histopathological parameters, hormone receptors, and oncoproteins. Journal of Pathology 193 181-189.

Dano K, Romer J, Nielsen BS, Bjorn S, Pyke C, Rygaard J \& Lund LR 1999 Cancer invasion and tissue remodelingcooperation of protease systems and cell types. Acta Pathologica, Microbiologica et Immunologica Scandinavica 107 120-127.
Davidson JM, Gorringe KL, Chin SF, Orsetti B, Besret C, Courtay-Cahen C, Roberts I, Theillet C, Caldas C \& Edwards PA 2000 Molecular cytogenetic analysis of breast cancer cell lines. British Journal of Cancer 83 1309-1317.

Davies EL, Gee JM, Cochrane RA, Jiang WG, Sharma AK, Nicholson RI \& Mansel RE 1999 The immunohistochemical expression of desmoplakin and its role in vivo in the progression and metastasis of breast cancer. European Journal of Cancer 35 902-907.

De Larco JE, Wuertz BR, Rosner KA, Erickson SA, Gamache DE, Manivel JC \& Furcht LT 2001 A potential role for interleukin- 8 in the metastatic phenotype of breast carcinoma cells. American Journal of Pathology 158 639-646.

Dellas A, Torhorst J, Schultheiss E, Mihatsch MJ \& Moch H 2002 DNA sequence losses on chromosomes $11 \mathrm{p}$ and $18 \mathrm{q}$ are associated with clinical outcome in lymph node-negative ductal breast cancer. Clinical Cancer Research 8 1210-1216.

Deng G, Lu Y, Zlotnikov G, Thor AD \& Smith HS 1996 Loss of heterozygosity in normal tissue adjacent to breast carcinomas. Science 274 2057-2059.

Deugnier MA, Teuliere J, Faraldo MM, Thiery JP \& Glukhova MA 2002 The importance of being a myoepithelial cell. Breast Cancer Research 4 224-230.

Domagala W, Wozniak L, Lasota J, Weber K \& Osborn M 1990 Vimentin is preferentially expressed in high-grade ductal and medullary, but not in lobular breast carcinomas. American Journal of Pathology 137 1059-1064.

Donnellan R, Kleinschmidt I \& Chetty R 2001 Cyclin E immunoexpression in breast ductal carcinoma: pathologic correlations and prognostic implications. Human Pathology 32 89-94.

Dontu G, Al-Hajj M, Abdallah WM, Clarke MF \& Wicha MS 2003 Stem cells in normal breast development and breast cancer. Cell Proliferation 36 59-72.

Douglas-Jones AG, Gupta SK, Attanoos RL, Morgan JM \& Mansel RE 1996 A critical appraisal of six modern classifications of ductal carcinoma in situ of the breast (DCIS): correlation with grade of associated invasive carcinoma. Histopathology 29 397-409.

Du Y, Carling T, Fang W, Piao Z, Sheu JC \& Huang S 2001 Hypermethylation in human cancers of the RIZ1 tumor suppressor gene, a member of a histone/protein methyltransferase superfamily. Cancer Research $\mathbf{6 1}$ 8094-8099.

Elenbaas B \& Weinberg RA 2001 Heterotypic signaling between epithelial tumor cells and fibroblasts in carcinoma formation. Experimental Cell Research 264 169-184.

Elston CW \& Ellis IO 2002 Pathological prognostic factors in breast cancer. I. The value of histological grade in breast cancer: experience from a large study with long-term followup. C. W. Elston \& I. O. Ellis. Histopathology 1991; 19; 403-410. Histopathology 41151.

Esworthy RS, Baker MA \& Chu FF 1995 Expression of selenium-dependent glutathione peroxidase in human breast tumor cell lines. Cancer Research 55 957-962.

Etzell JE, Devries S, Chew K, Florendo C, Molinaro A, Ljung BM \& Waldman FM 2001 Loss of chromosome 16q in lobular carcinoma in situ. Human Pathology 32 292-296. 
Fackler MJ, McVeigh M, Evron E, Garrett E, Mehrotra J, Polyak K, Sukumar S \& Argani P 2003 DNA methylation of RASSF1A, HIN-1, RAR-beta, Cyclin D2 and Twist in in situ and invasive lobular breast carcinoma. International Journal of Cancer 107 970-975.

Farabegoli F, Hermsen MA, Ceccarelli C, Santini D, Weiss MM, Meijer GA \& Diest PJ 2004 Simultaneous chromosome 1q gain and $16 \mathrm{q}$ loss is associated with steroid receptor presence and low proliferation in breast carcinoma. Modern Pathology $17449-455$.

Ferlicot S, Vincent-Salomon A, Medioni J, Genin P, Rosty C, Sigal-Zafrani B, Freneaux P, Jouve M, Thiery JP \& SastreGarau X 2004 Wide metastatic spreading in infiltrating lobular carcinoma of the breast. European Journal of Cancer 40 336-341.

Finlin BS, Gau CL, Murphy GA, Murphy GA, Shao H, Kimel T, Seitz RS, Chiu YF, Botstein D, Brown PO, Der CJ, Tamanoi F, Andres DA \& Perou CM 2001 RERG is a novel rasrelated, estrogen-regulated and growth-inhibitory gene in breast cancer. Journal of Biological Chemistry 276 42259-42267.

Forozan F, Veldman R, Ammerman CA, Parsa NZ, Kallioniemi A, Kallioniemi OP \& Ethier SP 1999 Molecular cytogenetic analysis of 11 new breast cancer cell lines. British Journal of Cancer 81 1328-1334.

Forozan F, Mahlamaki EH, Monni O, Chen Y, Veldman R, Jiang Y, Gooden GC, Ethier SP, Kallioniemi A \& Kallioniemi OP 2000 Comparative genomic hybridization analysis of 38 breast cancer cell lines: a basis for interpreting complementary DNA microarray data. Cancer Research $\mathbf{6 0}$ 4519-4525.

Foster KW, Frost AR, McKie-Bell P, Lin CY, Engler JA, Grizzle WE \& Ruppert JM 2000 Increase of GKLF messenger RNA and protein expression during progression of breast cancer. Cancer Research $606488-6495$.

Foulkes WD 2004 BRCA1 functions as a breast stem regulator. Journal of Medical Genetics 41 1-5.

Foulkes WD, Metcalfe K, Hanna W, Lynch HT, Ghadirian P, Tung N, Olopade O, Weber B, McLennan J, Olivotto IA, Sun P, Chappuis PO, Begin LR, Brunet JS \& Narod SA 2003 Disruption of the expected positive correlation between breast tumor size and lymph node status in BRCA1-related breast carcinoma. Cancer 98 1569-1577.

Friedline JA, Garrett SH, Somji S, Todd JH \& Sens DA 1998 Differential expression of the MT-1E gene in estrogenreceptor-positive and -negative human breast cancer cell lines. American Journal of Pathology 152 23-27.

Frolik D, Caduff R \& Varga Z 2001 Pleomorphic lobular carcinoma of the breast: its cell kinetics, expression of oncogenes and tumour suppressor genes compared with invasive ductal carcinomas and classical infiltrating lobular carcinomas. Histopathology 39 503-513.

Frykberg ER 1999 Lobular carcinoma in situ of the breast. Breast Journal 5 296-303.

Fuqua SA 2001 The role of estrogen receptors in breast cancer metastasis. Journal of Mammary Gland Biology and Neoplasia 6 407-417.

Gandhi A, Holland PA, Knox WF, Potten CS \& Bundred NJ 1998 Evidence of significant apoptosis in poorly differentiated ductal carcinoma in situ of the breast. British Journal of Cancer 78 788-794.

Gee JM, Robertson JF, Ellis IO, Willsher P, McClelland RA, Hoyle HB, Kyme SR, Finlay P, Blamey RW \& Nicholson RI 1994 Immunocytochemical localization of BCL-2 protein in human breast cancers and its relationship to a series of prognostic markers and response to endocrine therapy. International Journal of Cancer 59 619-628.

Ghosh MG, Thompson DA \& Weigel RJ 2000 PDZK1 and GREB1 are estrogen-regulated genes expressed in hormoneresponsive breast cancer. Cancer Research 60 6367-6375.

Gill S, Peston D, Vonderhaar BK \& Shousha S 2001 Expression of prolactin receptors in normal, benign, and malignant breast tissue: an immunohistological study. Journal of Clinical Pathology 54 956-960.

Gillesby BE \& Zacharewski TR 1999 pS2 (TFF1) levels in human breast cancer tumor samples: correlation with clinical and histological prognostic markers. Breast Cancer Research and Treatment 56 253-265.

Glockner S, Lehmann U, Wilke N, Kleeberger W, Langer F \& Kreipe H 2001 Amplification of growth regulatory genes in intraductal breast cancer is associated with higher nuclear grade but not with the progression to invasiveness. Laboratory Investigations 81 565-571.

Goldstein NS 2002 Does the level of E-cadherin expression correlate with the primary breast carcinoma infiltration pattern and type of systemic metastases? American Journal of Clinical Pathology 118 425-434.

Goldstein NS, Bassi D, Watts JC, Layfield LJ, Yaziji H \& Gown AM 2001 E-cadherin reactivity of 95 noninvasive ductal and lobular lesions of the breast. Implications for the interpretation of problematic lesions. American Journal of Clinical Pathology 115 534-542.

Gonzalez MA, Pinder SE, Callagy G, Vowler SL, Morris LS, Bird K, Bell JA, Laskey RA \& Coleman N 2003 Minichromosome maintenance protein 2 is a strong independent prognostic marker in breast cancer. Journal of Clinical Oncology 21 4306-4313.

Grøndahl-Hansen J, Christensen IJ, Rosenquist C, Brunner N, Mouridsen HT, Dano K \& Blichert-Toft M 1993 High levels of urokinase-type plasminogen activator and its inhibitor PAI-1 in cytosolic extracts of breast carcinomas are associated with poor prognosis. Cancer Research $\mathbf{5 3}$ 2513-2521.

Gruvberger S, Ringner M, Chen Y, Panavally S, Panavally S, Saal LH, Borg A, Ferno M, Peterson C \& Meltzer PS 2001 Estrogen receptor status in breast cancer is associated with remarkably distinct gene expression patterns. Cancer Research 61 5979-5988.

Gudas JM, Nguyen H, Klein RC, Katayose D, Seth P \& Cowan KH 1995 Differential expression of multiple MDM2 messenger RNAs and proteins in normal and tumorigenic breast epithelial cells. Clinical Cancer Research 1 71-80.

Guenther K, Merkelbach-Bruse S, Amo-Takyi BK, Handt S, Schroder W \& Tietze L 2001 Differences in genetic alterations between primary lobular and ductal breast cancers detected by comparative genomic hybridization. Journal of Pathology 193 40-47. 
Gupta A, Deshpande CG \& Badve S 2003 Role of E-cadherins in development of lymphatic tumor emboli. Cancer $\mathbf{9 7}$ 2341-2347.

Hall RE, Lee CS, Alexander IE, Shine J, Clarke CL \& Sutherland RL 1990 Steroid hormone receptor gene expression in human breast cancer cells: inverse relationship between oestrogen and glucocorticoid receptor messenger RNA levels. International Journal of Cancer 46 1081-1087.

Hampl M, Hampl JA, Schwarz P, Frank S, Hahn M, Schackert G, Saeger HD \& Schackert HK 1998-1999 Accumulation of genetic alterations in brain metastases of sporadic breast carcinomas is associated with reduced survival after metastasis. Invasion Metastasis 18 81-95.

Hartsough MT \& Steeg PS 2000 Nm23/nucleoside diphosphate kinase in human cancers. Journal of Bioenergetics and Biomembranes 32 301-308.

Hartsough MT, Clare SE, Mair M, Elkahloun AG, Sgroi D, Osborne CK, Clark G \& Steeg PS 2001 Elevation of breast carcinoma Nm23-H1 metastasis suppressor gene expression and reduced motility by DNA methylation inhibition. Cancer Research $612320-2327$.

Hayes DF, Isaacs C \& Stearns V 2002 Prognostic factors in breast cancer: current and new predictors of metastasis. Journal of Mammary Gland Biology and Neoplasia 6 375-392.

Heppner KJ, Matrisian LM, Jensen RA \& Rodgers WH 1996 Expression of most matrix metalloproteinase family members in breast cancer represents a tumor-induced host response. American Journal of Pathology 149 273-282.

Hoch RV, Thompson DA, Baker RJ \& Weigel RJ 1999 GATA-3 is expressed in association with estrogen receptor in breast cancer. International Journal of Cancer 84 122-128.

Hoff ER, Tubbs RR, Myles JL \& Procop GW 2002 HER2/neu amplification in breast cancer: stratification by tumor type and grade. American Journal of Clinical Pathology 117 916-921.

Hoover KB, Liao SY \& Bryant PJ 1998 Loss of the tight junction MAGUK ZO-1 in breast cancer: relationship to glandular differentiation and loss of heterozygosity. American Journal of Pathology 153 1767-1773.

Hoque A, Sneige N, Sahin AA, Menter DG, Bacus JW, Hortobagyi, GN \& Lippman SM 2002 Her-2/neu gene amplification in ductal carcinoma in situ of the breast. Cancer Epidemiology Biomarkers and Prevention 11 587-590.

Hori M, Shimazaki J, Inagawa S, Itabashi M \& Hori M 2002 Overexpression of MDM2 oncoprotein correlates with possession of estrogen receptor alpha and lack of MDM2 mRNA splice variants in human breast cancer. Breast Cancer Research and Treatment 71 77-83.

Horiguchi J, Iino Y, Takei H, Maemura M, Koibuchi Y, Takeyoshi I, Ohwada S, Yokoe T, Nakajima T, Oyama T \& Morishita Y 2000 Immunohistochemical study on primary and recurrent tumors in patients with local recurrence in the conserved breast. Oncology Reports 7 295-298.

Huang E, Cheng SH, Dressman H, Pittman J, Tsou MH, Horng CF, Bild A, Iversen ES, Liao M, Chen CM, West M, Nevins JR \& Huang AT 2003 Gene expression predictors of breast cancer outcomes. Lancet 361 1590-1596.

Hui R, Macmillan RD, Kenny FS, Musgrove EA, Blamey RW, Nicholson RI, Robertson JF \& Sutherland RL 2000 INK4a gene expression and methylation in primary breast cancer: overexpression of p16INK4a messenger RNA is a marker of poor prognosis. Clinical Cancer Research 6 2777-2787.

Iglehart JD, Kerns BJ, Huper G \& Marks JR 1995 Maintenance of DNA content and erbB-2 alterations in intraductal and invasive phases of mammary cancer. Breast Cancer Research and Treatment 34 253-263.

Ingvarsson S 1999 Molecular genetics of breast cancer progression. Seminars in Cancer Biology 9 277-288.

Jensen EV, Cheng G, Palmieri C, Saji S, Makela S, Van Noorden S, Wahlstrom T, Warner M, Coombes RC \& Gustafsson JA 2001 Estrogen receptors and proliferation markers in primary and recurrent breast cancer. PNAS 98 15197-15202.

Jin R, Bay BH, Chow VT, Tan PH \& Lin VC 2000 Metallothionein 1E mRNA is highly expressed in oestrogen receptor-negative human invasive ductal breast cancer. British Journal of Cancer 83 319-323.

Jones C, Nonni AV, Fulford L, Merrett S, Chaggar R, Eusebi V \& Lakhani SR 2001 CGH analysis of ductal carcinoma of the breast with basaloid/myoepithelial cell differentiation. British Journal of Cancer 85 422-427.

Kayser K, Biechele U, Kayser G, Dienemann H, Andre S, Bovin NV \& Gabius HJ 1998 Pulmonary metastases of breast carcinomas: ligandohistochemical, nuclear, and structural analysis of primary and metastatic tumors with emphasis on period of occurrence of metastases and survival. Journal of Surgical Oncology 69 137-146.

Keshgegian AA \& Cnaan A 1995 Proliferation markers in breast carcinoma. Mitotic figure count, S-phase fraction, proliferating cell nuclear antigen, Ki-67 and MIB-1. American Journal of Clinical Pathology 104 42-49.

Kleer CG, van Golen KL, Zhang Y, Wu ZF, Rubin MA \& Merajver SD 2002 Characterization of RhoC expression in benign and malignant breast disease: a potential new marker for small breast carcinomas with metastatic ability. American Journal of Pathology 160 579-584.

Klein CA, Blankenstein TJ, Schmidt-Kittler O, Petronio M, Polzer B, Stoecklein NH \& Riethmuller G 2002 Genetic heterogeneity of single disseminated tumour cells in minimal residual cancer. Lancet $360683-689$.

Klijn JG, Berns PM, Schmitz PI \& Foekens JA 1992 The clinical significance of epidermal growth factor receptor (EGF-R) in human breast cancer: a review of 5232 patients. Endocrine Reviews 13 3-17.

Kominsky SL, Argani P, Korz D, Evron E, Raman V, Garrett E, Rein A, Sauter G, Kallioniemi OP \& Sukumar S 2003 Loss of the tight junction protein claudin-7 correlates with histological grade in both ductal carcinoma in situ and invasive ductal carcinoma of the breast. Oncogene 22 2021-2033.

Kononen J, Bubendorf L, Kallioniemi A, Barlund M, Schraml P, Leighton S, Torhorst J, Mihatsch MJ, Sauter G \& Kallioniemi OP 1998 Tissue microarrays for high-throughput molecular profiling of tumor specimens. Nature Medicine 4 844-847.

Korkola JE, DeVries S, Fridlyand J, Hwang ES, Estep AL, Chen YY, Chew KL, Dairkee SH, Jensen RM \& Waldman FM 2003 Differentiation of lobular versus ductal breast 
carcinomas by expression microarray analysis. Cancer Research 63 7167-7175.

Korsching E, Packeisen J, Agelopoulos K, Eisenacher M, Voss R, Isola J, van Diest PJ, Brandt B, Boecker W \& Buerger H 2002 Cytogenetic alterations and cytokeratin expression patterns in breast cancer: integrating a new model of breast differentiation into cytogenetic pathways of breast carcinogenesis. Laboratory Investigations 82 1525-1533.

Krisnamurthy S \& Sneige N 2002 Molecular and biologic markers of premalignant lesions of human breast. Advances in Anatomic Pathology 9 185-197.

Kruger S, Fahrenkrog T \& Muller H 1999 Proliferative and apoptotic activity in lobular breast carcinoma. International Journal of Molecular Medicine 4 171-174.

Kuang WW, Thompson DA, Hoch RV \& Weigel RJ 1998 Differential screening and suppression subtractive hybridization identified genes differentially expressed in an estrogen receptor-positive breast carcinoma cell line. Nucleic Acids Research 26 1116-1123.

Kytola S, Rummukainen J, Nordgren A, Karhu R, Farnebo F, Isola J \& Larsson C 2000 Chromosomal alterations in 15 breast cancer cell lines by comparative genomic hybridization and spectral karyotyping. Genes Chromosomes Cancer $\mathbf{2 8}$ 308-317.

Lacroix M \& Leclercq G 2004a Relevance of breast cancer cell lines as models for breast tumours: an update. Breast Cancer Research and Treatment 83 249-289.

Lacroix M \& Leclercq G 2004b About GATA3, HNF3A and $\mathrm{XBP} 1$, three genes co-expressed with the oestrogen receptor- $\alpha$ gene (ESR1) in breast cancer. Molecular and Cellular Endocrinology 219 1-7.

Lacroix M, Siwek B \& Body JJ 1996 Effects of secretory products of breast cancer cells on osteoblast-like cells. Breast Cancer Research and Treatment 38 209-216.

Lacroix M, Marie PJ \& Body JJ 2000 Protein production by osteoblasts: modulation by breast cancer cell-derived factors. Breast Cancer Research and Treatment 61 59-67.

Lacroix M, Querton G, Hennebert P, Larsimont D \& Leclercq G 2001 Estrogen receptor analysis in primary breast tumors by ligand-binding assay, immunocytochemical assay, and northern blot: a comparison. Breast Cancer Research and Treatment 67 263-271.

Lacroix M, Zammatteo N, Remacle J \& Leclercq G 2002 A lowdensity DNA microarray for analysis of markers in breast cancer. International Journal of Biological Markers 17 5-23.

Lah TT, Cercek M, Blejec A, Kos J, Gorodetsky E, Somers R \& Daskal I 2000 Cathepsin B, a prognostic indicator in lymph node-negative breast carcinoma patients: comparison with cathepsin D, cathepsin L, and other clinical indicators. Clinical Cancer Research 6 578-584.

Lampejo OT, Barnes DM, Smith P \& Millis RR 1994 Evaluation of infiltrating ductal carcinomas with a DCIS component: correlation of the histologic type of the in situ component with grade of the infiltrating component. Seminars in Diagnostic Pathology 11 215-222.

Larramendy ML, Lushnikova T, Bj]orkqvist AM, Wistuba II, Virmani AK, Shivapurkar N, Gazdar AF \& Knuutila S 2000 Comparative genomic hybridization reveals complex genetic changes in primary breast cancer tumors and their cell lines. Cancer Genetics and Cytogenetics 119 132-138.

Leclercq G, Lacroix M, Seo HS \& Larsimont D 2002

Mechanisms regulating oestrogen receptor alpha expression in breast cancer. In Molecular Mechanisms of Action of Steroid Hormone Receptors, pp 62-75. Eds M KrsticDemonacos \& C Demonacos. Trivandrum, Kerala, India: Research Signpost

Lee AH, Dublin EA, Bobrow LG \& Poulsom R 1998 Invasive lobular and invasive ductal carcinoma of the breast show distinct patterns of vascular endothelial growth factor expression and angiogenesis. Journal of Pathology 185 394-401.

Lehmann U, Langer F, Feist H, Glockner S, Hasemeier B \& Kreipe H 2002 Quantitative assessment of promoter hypermethylation during breast cancer development. American Journal of Pathology 160 605-612.

Lehr HA, Folpe A, Yaziji H, Kommoss F \& Gown AM 2000 Cytokeratin 8 immunostaining pattern and E-cadherin expression distinguish lobular from ductal breast carcinoma. American Journal of Clinical Pathology 114 190-196.

Li CI, Anderson BO, Daling JR \& Moe RE 2003a Trends in incidence rates of invasive lobular and ductal breast carcinoma. Journal of the American Medical Association 289 1421-1424.

Li Y, Welm B, Podsypanina K, Huang S, Chamorro M, Zhang X, Rowlands T, Egeblad M, Cowin P, Werb Z, Tan LK, Rosen JM \& Varmus HE 2003b Evidence that transgenes encoding components of the Wnt signaling pathway preferentially induce mammary cancers from progenitor cells. PNAS 100 15853-15858.

Lipponen P 1999 Apoptosis in breast cancer: relationship with other pathological parameters. Endocrine-Related Cancer 6 13-16.

Liu WM, Guerra-Vladusic FK, Kurakata S, Lupu R \& KohwiShigematsu T 1999 HMG-I(Y) recognizes base-unpairing regions of matrix attachment sequences and its increased expression is directly linked to metastatic breast cancer phenotype. Cancer Research 59 5695-5703.

Loden M, Stighall M, Nielsen NH, Roos G, Emdin SO, Ostlund H \& Landberg G 2002 The cyclin D1 high and cyclin E high subgroups of breast cancer: separate pathways in tumorogenesis based on pattern of genetic aberrations and inactivation of the pRb node. Oncogene 21 4680-4690.

Look MP, van Putten WL, Duffy MJ, Harbeck N, Christensen IJ, Thomssen C, Kates R, Spyratos F, Ferno M, Eppenberger-Castori S, Sweep CG, Ulm K, Peyrat JP, Martin PM, Magdelenat H, Brunner N, Duggan C, Lisboa BW, Bendahl PO, Quillien V, Daver A, Ricolleau G, Meijer-van Gelder ME, Manders P, Fiets WE, Blankenstein MA, Broet P, Romain S, Daxenbichler G, Windbichler G, Cufer T, Borstnar S, Kueng W, Beex LV, Klijn JG, O'Higgins N, Eppenberger U, Janicke F, Schmitt M \& Foekens JA 2002 Pooled analysis of prognostic impact of urokinase-type plasminogen activator and its inhibitor PAI-1 in 8377 breast cancer patients. Journal of the National Cancer Institute 94 116-128.

Loveday RL, Greenman J, Simcox DL, Speirs V, Drew PJ, Monson JR \& Kerin MJ 2000 Genetic changes in breast 
cancer detected by comparative genomic hybridization. International Journal of Cancer 86 494-500.

Lundin C \& Mertens F 1998 Cytogenetics of benign breast lesions. Breast Cancer Research and Treatment 51 1-15.

Ma XJ, Salunga R, Tuggle JT, Gaudet J, Enright E, McQuary P, Payette T, Pistone M, Stecker K, Zhang BM, Zhou YX, Varnholt H, Smith B, Gadd M, Chatfield E, Kessler J, Baer TM, Erlander MG \& Sgroi DC 2003 Gene expression profiles of human breast cancer progression. PNAS 100 5974-5979.

Malik K \& Brown KW 2000 Epigenetic gene deregulation in cancer. British Journal of Cancer 83 1583-1588.

McCarthy K, Maguire T, McGreal G, McDermott E, O'Higgins N \& Duffy MJ 1999 High levels of tissue inhibitor of metalloproteinase-1 predict poor outcome in patients with breast cancer. International Journal of Cancer 84 44-48.

Mendelin J, Grayson M, Wallis T \& Visscher DW 1999 Analysis of chromosome aneuploidy in breast carcinoma progression by using fluorescence in situ hybridization. Laboratory Investigations 79 387-393.

Millis RR, Barnes DM, Lampejo OT, Egan MK \& Smith P 1998 Tumor grade does not change between primary and recurrent mammary carcinoma. European Journal of Cancer 34 548-553.

Miyoshi Y, Ando A, Hasegawa S, Ishitobi M, Taguchi T, Tamaki Y \& Noguchi S 2003 High expression of steroid sulfatase mRNA predicts poor prognosis in patients with estrogen receptor-positive breast cancer. Clinical Cancer Research 9 2288-2293.

Molino A, Micciolo R, Turazza M, Bonetti F, Piubello Q, Bonetti A, Nortilli R, Pelosi G \& Cetto GL 1997 Ki-67 immunostaining in 322 primary breast cancers: associations with clinical and pathological variables and prognosis. International Journal of Cancer 74 433-437.

Mommers EC, Leonhart AM, Falix F, Michalides R, Meijer CJ, Baak JP \& Diest PJ 2001 Similarity in expression of cell cycle proteins between in situ and invasive ductal breast lesions of same differentiation grade. Journal of Pathology 194 327-333.

Moore MA 2001 The role of chemoattraction in cancer metastases. Bioessays 23 674-676.

Moriya T \& Silverberg SG 1994 Intraductal carcinoma (ductal carcinoma in situ) of the breast. A comparison of pure noninvasive tumors with those including different proportions of infiltrating carcinoma. Cancer 74 2972-2978.

Moscow JA, Townsend AJ, Goldsmith ME, Whang-Peng J, Vickers PJ, Poisson R, Legault-Poisson S, Myers CE \& Cowan KH 1988 Isolation of the human anionic glutathione S-transferase cDNA and the relation of its gene expression to estrogen-receptor content in primary breast cancer. PNAS $\mathbf{8 5}$ 6518-6522.

Nakatani K, Thompson DA, Barthel A, Sakaue H, Liu W, Weigel RJ \& Roth RA 1999 Up-regulation of Akt3 in estrogen receptor-deficient breast cancers and androgenindependent prostate cancer lines. Journal of Biological Chemistry $27421528-21532$.

Nedergaard L, Haerslev T \& Jacobsen GK 1995 Immunohistochemical study of estrogen receptors in primary breast carcinomas and their lymph node metastases including comparison of two monoclonal antibodies. Acta Pathologica, Microbiologica et Immunologica Scandinavica 103 20-24.
Nielsen NH, Emdin SO, Cajander J \& Landberg G 1997 Deregulation of cyclin E and D1 in breast cancer is associated with inactivation of the retinoblastoma protein. Oncogene $\mathbf{1 4}$ 295-304.

Nishizaki T, DeVries S, Chew K, Goodson WH 3rd, Ljung BM, Thor A \& Waldman FM 1997 Genetic alterations in primary breast cancers and their metastases: direct comparison using modified comparative genomic hybridization. Genes Chromosomes Cancer 19 267-272.

Oberst M, Anders J, Xie B, Singh B, Ossandon M, Johnson M, Dickson RB \& Lin CY 2001 Matriptase and HAI-1 are expressed by normal and malignant epithelial cells in vitro and in vivo. American Journal of Pathology 158 1301-1311.

Oh YL, Choi JS, Song SY, Ko YH, Han BK, Nam SJ \& Yang JH 2001 Expression of p21Waf1, p27Kip1 and cyclin D1 proteins in breast ductal carcinoma in situ: Relation with clinicopathologic characteristics and with p53 expression and estrogen receptor status. Pathology International 51 94-99.

Pandis N, Idvall I, Bardi G, Jin Y, Gorunova L, Mertens F, Olsson H, Ingvar C, Beroukas K, Mitelman F \& Heim S 1996 Correlation between karyotypic pattern and clincopathologic features in 125 breast cancer cases. International Journal of Cancer 66 191-196.

Paredes J, Milanezi F, Viegas L, Amendoeira I \& Schmitt F 2002 P-cadherin expression is associated with high-grade ductal carcinoma in situ of the breast. Virchows Archivs 440 16-21.

Park K, Han S, Kim HY \& Ko I 2001 Cytologic evaluation of cyclin D1 expression in primary breast carcinoma. Cancer $\mathbf{9 3}$ 211-215.

Parker C, Rampaul RS, Pinder SE, Bell JA, Wencyk PM, Blamey RW, Nicholson RI \& Robertson JF 2001 E-cadherin as a prognostic indicator in primary breast cancer. British Journal of Cancer 85 1958-1963.

Paz MF, Fraga MF, Avila S, Guo M, Pollan M, Herman JG \& Esteller M 2003 A systematic profile of DNA methylation in human cancer cell lines. Cancer Research 63 1114-1121.

Pedrocchi M, Schafer BW, Mueller H, Eppenberger U \& Heizmann CW 1994 Expression of Ca(2+)-binding proteins of the S100 family in malignant human breast-cancer cell lines and biopsy samples. International Journal of Cancer $\mathbf{5 7}$ 684-690.

Peirce SK, Chen WY \& Chen WY 2001 Quantification of prolactin receptor mRNA in multiple human tissues and cancer cell lines by real time RT-PCR. Journal of Endocrinology $171 \mathrm{R} 1-\mathrm{R} 4$.

Perou CM, Sorlie T, Eisen MB, van de Rijn M, Jeffrey SS, Rees CA, Pollack JR, Ross DT, Johnsen H, Akslen LA, Fluge O, Pergamenschikov A, Williams C, Zhu SX, Lonning PE, Borresen-Dale AL, Brown PO \& Botstein D 2000 Molecular portraits of human breast tumors. Nature 406 747-752.

Persson K, Pandis N, Mertens F, Borg A, Baldetorp B, Killander D \& Isola J 1999 Chromosomal aberrations in breast cancer: a comparison between cytogenetics and comparative genomic hybridization. Genes Chromosomes and Cancer 25 115-122.

Petersen OW, Gudjonsson T, Villadsen R, Bissell MJ \& RonnovJessen L 2003 Epithelial progenitor cell lines as models of normal breast morphogenesis and neoplasia. Cell Proliferation 36 33-44. 
Polyak K 2001 On the birth of breast cancer. Biochimica et Biophysica Acta 1552 1-13.

Poulsom R, Hanby AM, Lalani EN, Hauser F, Hoffmann W \& Stamp GW 1997 Intestinal trefoil factor (TFF 3) and pS2 (TFF 1), but not spasmolytic polypeptide (TFF 2) mRNAs are co-expressed in normal, hyperplastic, and neoplastic human breast epithelium. Journal of Pathology 183 30-38.

Radhi JM 2000 Immunohistochemical analysis of pleomorphic lobular carcinoma: higher expression of p53 and chromogranin and lower expression of ER and PgR. Histopathology 36 156-160.

Ramaswamy S, Ross KN, Lander ES \& Golub TR 2003 A molecular signature of metastasis in primary solid tumors. Nature Genetics 33 49-54.

Reed W, Florems VA, Holm R, Hannisdal E \& Nesland JM 1999 Elevated levels of p27, p21 and cyclin D1 correlate with positive oestrogen and progesterone receptor status in nodenegative breast carcinoma patients. Virchows Archivs $\mathbf{4 3 5}$ 116-124.

Remacle A, McCarthy K, Noel A, Maguire T, McDermott E, O'Higgins N, Foidart JM \& Duffy MJ 2000 High levels of TIMP-2 correlate with adverse prognosis in breast cancer. International Journal of Cancer 89 118-121.

Rennstam K, Ahlstedt-Soini M, Baldetorp B, Bendahl PO, Borg A, Karhu R, Tanner M, Tirkkonen M \& Isola J 2003 Patterns of chromosomal imbalances define subgroups of breast cancer with distinct clinical features and prognosis. A study of 305 tumors by comparative genomic hybridization. Cancer Research 63 8861-8868.

Richard F, Pacyna-Gengelbach M, Schlüns K, Fleige B, Winzer KJ, Szymas J, Dietel M, Petersen I \& Schwendel A 2000 Patterns of chromosomal imbalances in invasive breast cancer. International Journal of Cancer 89 305-310.

Ried T, Just KE, Holtgreve-Grez H, du Manoir S, Speicher MR, E, C, Blegen H, Zetterberg A, Cremer T \& Auer G 1995 Comparative genomic hybridization of formalin-fixed, paraffin-embedded breast tumors reveals different patterns of chromosomal gains and losses in fibroadenomas and diploid and aneuploid carcinomas. Cancer Research 55 5415-5423.

Rilke F, Colnaghi MI, Cascinelli N, Andreola S, Baldini MT, Bufalino R, Della Porta G, Menard S, Pierotti MA \& Testori A 1991 Prognostic significance of HER-2/neu expression in breast cancer and its relationship to other prognostic factors. International Journal of Cancer 49 44-49.

Ringberg A, Anagnostaki L, Anderson H, Idvall I, Ferno M \& South Sweden Breast Cancer Group 2001 Cell biological factors in ductal carcinoma in situ (DCIS) of the breastrelationship to ipsilateral local recurrence and histopathological characteristics. European Journal of Cancer 37 1514-1522.

Ristimaki A, Sivula A, Lundin J, Lundin M, Salminen T, Haglund C, Joensuu H \& Isola J 2002 Prognostic significance of elevated cyclooxygenase- 2 expression in breast cancer. Cancer Research 62 632-635.

Rosenthal SI, Depowski PL, Sheehan CE \& Ross JS 2002 Comparison of HER-2/neu oncogene amplification detected by fluorescence in situ hybridization in lobular and ductal breast cancer. Applied Immunohistochemistry and Molecular Morphology 10 40-46.
Rosner A, Miyoshi K, Landesman-Bollag E, Xu X, Seldin DC, Moser AR, MacLeod CL, Shyamala G, Gillgrass AE \& Cardiff RD 2002 Histological differences between ErbB/Ras and Wnt pathway transgenic mammary tumors. American Journal of Pathology 161 1087-1097.

Ross DT \& Perou CM 2001 A comparison of gene expression signatures from breast tumors and breast tissue derived cell lines. Disease Markers 17 99-109.

Ross DT, Scherf U, Eisen MB, Perou CM, Rees C, Spellman P, Iyer V, Jeffrey SS, Van de Rijn M, Waltham M, Pergamenschikov A, Lee JC, Lashkari D, Shalon D, Myers TG, Weinstein JN, Botstein D \& Brown PO 2000 Systematic variation in gene expression patterns in human cancer cell lines. Nature Genetics 24 227-235.

Roylance R, Gorman P, Harris W, Liebmann R, Barnes D, Hanby A \& Sheer D 1999 Comparative genomic hybridization of breast tumors stratified by histological grade reveals new insights into the biological progression of breast cancer. Cancer Research 59 1433-1436.

Roylance R, Gorman P, Hanby A \& Tomlinson I 2002 Allelic imbalance analysis of chromosome 16q shows that grade I and grade III invasive ductal breast cancers follow different genetic pathways. Journal of Pathology 196 32-36.

Rudolph P, Olsson H, Bonatz G, Ratjen V, Bolte H, Baldetorp B, Ferno M, Parwaresch R \& Alm P 1999a Correlation between p53, c-erbB-2, and topoisomerase II alpha expression, DNA ploidy, hormonal receptor status and proliferation in 356 node-negative breast carcinomas: prognostic implications. Journal of Pathology 187 207-216.

Rudolph P, MacGrogan G, Bonichon F, Frahm SO, de Mascarel I, Trojani M, Durand M, Avril A, Coindre JM \& Parwaresch R $1999 b$ Prognostic significance of Ki-67 and topoisomerase IIalpha expression in infiltrating ductal carcinoma of the breast. A multivariate analysis of 863 cases. Breast Cancer Research and Treatment 55 61-71.

Sato T, Akiyama F, Sakamoto G, Kasumi F \& Nakamura Y 1991 Accumulation of genetic alterations and progression of primary breast cancer. Cancer Research 51 5794-5799.

Schnack Nielsen B, Rank F, Engelholm LH, Holm A, Dano K \& Behrendt N 2002 Urokinase receptor-associated protein (UPARAP) is expressed in connection with malignant as well as benign lesions of the human breast and occurs in specific populations of stromal cells. International Journal of Cancer 98 656-664.

Schwendel A, Richard F, Langreck H, Kaufmann O, Lage H, Winzer KJ, Petersen I \& Dietel M 1998 Chromosome alterations in breast carcinomas: frequent involvement of DNA losses including chromosomes 4q and 21q. British Journal of Cancer 78 806-811.

Sgroi DC, Teng S, Robinson G, LeVangie R, Hudson JR Jr \& Elkahloun AG 1999 In vivo gene expression profile analysis of human breast cancer progression. Cancer Research $\mathbf{5 9}$ 5656-5661.

Shen CY, Yu JC, Lo YL, Kuo CH, Yue CT, Jou YS, Huang CS, Lung JC \& Wu CW 2000 Genome-wide search for loss of heterozygosity using laser capture microdissected tissue of breast carcinoma: an implication for mutator phenotype and breast cancer pathogenesis. Cancer Research $603884-3892$. 
Sherbet GV \& Lakshmi MS 1998 S100A4 (MTS1) calcium binding protein in cancer growth, invasion and metastasis. Anticancer Research 18 2415-2421.

Shimizu C, Fukutomi T, Tsuda H, Akashi-Tanaka S, Watanabe T, Nanasawa T \& Sugihara K 2000 c-erbB-2 protein overexpression and p53 immunoreaction in primary and recurrent breast cancer tissues. Journal of Surgical Oncology 73 17-20.

Sierra A, Price JE, Garcia-Ramirez M, Mendez O, Lopez L \& Fabra A 1997 Astrocyte-derived cytokines contribute to the metastatic brain specificity of breast cancer cells. Laboratory Investigations 77 357-368.

Simon R, Nocito A, Hubscher T, Bucher C, Torhorst J, Schraml P, Bubendorf L, Mihatsch MM, Moch H, Wilber K, Schotzau A, Kononen J \& Sauter G 2001 Patterns of her-2/neu amplification and overexpression in primary and metastatic breast cancer. Journal of the National Cancer Institute $\mathbf{9 3}$ 1141-1146.

Simon R, Mirlacher M \& Sauter G 2004 Tissue microarrays. Biotechniques 36 98-105.

Siwek B, Lacroix M, De Pollak C, Marie P \& Body JJ 1997 Secretory products of breast cancer cells specifically affect human osteoblastic cells: partial characterization of active factors. Journal of Bone and Mineral Research 12 552-560.

Smalley M \& Ashworth A 2003 Stem cells and breast cancer: A field in transit. Nature Reviews Cancer 3 832-844.

Sneige N, Wang J, Baker BA, Krishnamurthy S \& Middleton LP 2002 Clinical, histopathologic, and biologic features of pleomorphic lobular (ductallobular) carcinoma in situ of the breast: a report of 24 cases. Modern Pathology 15 1044-1050.

Sommers CL, Byers SW, Thompson EW, Torri JA \& Gelmann EP 1994 Differentiation state and invasiveness of human breast cancer cell lines. Breast Cancer Research and Treatment 31 325-335.

Sørlie T, Perou CM, Tibshirani R, Aas T, Geisler S, Johnsen H, Hastie T, Eisen MB, van de Rijn M, Jeffrey SS, Thorsen T, Quist H, Matese JC, Brown PO, Botstein D, Eystein Lonning P \& Borresen-Dale AL 2001 Gene expression patterns of breast carcinomas distinguish tumor subclasses with clinical implications. PNAS 98 10869-10874.

Sørlie T, Tibshirani R, Parker J, Hastie T, Marron JS, Nobel A, Deng S, Johnsen H, Pesich R, Geisler S, Demeter J, Perou CM, Lonning PE, Brown PO, Borresen-Dale AL \& Botstein D 2003 Repeated observation of breast tumor subtypes in independent gene expression data sets. PNAS 100 8418-8423.

Soslow RA, Carlson DL, Horenstein MG \& Osborne MP 2000 A comparison of cell cycle markers in well-differentiated lobular and ductal carcinomas. Breast Cancer Research and Treatment 61 161-170.

Sotiriou C, Neo SY, McShane LM, Korn EL, Long PM, Jazaeri A, Martiat P, Fox SB, Harris AL \& Liu ET 2003 Breast cancer classification and prognosis based on gene expression profiles from a population-based study. PNAS 100 10393-10398.

Speirs V 2002 Oestrogen receptor beta in breast cancer: good, bad or still too early to tell? Journal of Pathology 197 143-147.

Spizzo G, Obrist P, Ensinger C, Theurl I, Dunser M, Ramoni A, Gunsilius E, Eibl G, Mikuz G \& Gastl G 2002 Prognostic significance of Ep-CAM AND Her-2/neu overexpression in invasive breast cancer. International Journal of Cancer $\mathbf{9 8}$ 883-888.

Spyratos F, Andrieu C, Vidaud D, Briffod M, Vidaud M, Lidereau R \& Bieche I 2000 CCND1 mRNA overexpression is highly related to estrogen receptor positivity but not to proliferative markers in primary breast cancer. International Journal of Biological Markers 15 210-214.

Stemmer-Rachamimov AO, Wiederhold T, Nielsen GP, James M, Pinney-Michalowski D, Roy JE, Cohen WA, Ramesh V \& Louis DN 2001 NHE-RF, a merlin-interacting protein, is primarily expressed in luminal epithelia, proliferative endometrium, and estrogen receptor-positive breast carcinomas. American Journal of Pathology 158 57-62.

Sternlicht MD, Kedeshian P, Shao ZM, Safarians S \& Barsky SH 1997 The human myoepithelial cell is a natural tumor suppressor. Clinical Cancer Research 3 1949-1958.

Stingl J, Eaves CJ, Zandieh I \& Emerman JT 2001 Characterization of bipotent mammary epithelial progenitor cells in normal adult human breast tissue. Breast Cancer Research and Treatment 67 93-109.

Su L, Morgan PR \& Lane EB 1996 Expression of cytokeratin messenger RNA versus protein in the normal mammary gland and in breat cancer. Human Pathology 27 800-806.

Tagliabue E, Menard S, Robertson JF \& Harris L 1999 c-erbB-2 expression in primary breast cancer. International Journal of Biological Markers 14 16-26.

Teixeira MR, Pandis N \& Heim S 2002 Cytogenetic clues to breast carcinogenesis. Genes Chromosomes Cancer 33 1-16.

Tetu B, Brisson J, Wang CS, Lapointe H, Beaudry G \& Blanchette C 2001 Expression of cathepsin D, stromelysin-3, and urokinase by reactive stromal cells on breast carcinoma prognosis. Cancer 92 2957-2964.

Thompson DA \& Weigel RJ 1998 Characterization of a gene that is inversely correlated with estrogen receptor expression (ICERE-1) in breast carcinomas. European Journal of Biochemistry 252 169-177.

Toillon RA, Chopin V, Jouy N, Fauquette W, Boilly B \& Le Bourhis X 2002a Normal breast epithelial cells induce p53dependent apoptosis and p53-independent cell cycle arrest of breast cancer cells. Breast Cancer Research and Treatment 71 269-280.

Toillon RA, Descamps S, Adriaenssens E, Ricort JM, Bernard D, Boilly B \& Le Bourhis X $2002 b$ Normal breast epithelial cells induce apoptosis of breast cancer cells via Fas signaling. Experimental Cell Research 275 31-43.

Tong D, Schneeberger C, Czerwenka K, Schmutzler RK, Speiser P, Kucera E, Concin N, Kubista E, Leodolter S \& Zeillinger R 1999 Messenger RNA determination of estrogen receptor, progesterone receptor, $\mathrm{pS} 2$, and plasminogen activator inhibitor-1 by competitive reverse transcription-polymerase chain reaction in human breast cancer. Clinical Cancer Research 5 1497-1502.

Truong K, Guilly MN, Gerbault-Seureau M, Malfoy B, Vielh P \& Dutrillaux B 1999 Evidence for in vitro selection during cell culturing of breast cancer: detection by flow and image cytometry. Cancer Genetics and Cytogenetics $\mathbf{1 1 4}$ $154-155$. 
Tsuda H, Hirohashi S, Shimosato Y, Hirota T, Tsugane S, Watanabe S, Terada M \& Yamamoto H 1990 Correlation between histologic grade of malignancy and copy number of c-erbB-2 gene in breast carcinoma. A retrospective analysis of 176 cases. Cancer 65 1794-1800.

Tsuda H, Takarabe T, Hasegawa T, Murata T \& Hirohashi S 1999 Myoepithelial differentiation in high-grade invasive ductal carcinomas with large central acellular zones. Human Pathology 30 1134-1139.

Umekita Y, Ohi Y, Sagara Y \& Yoshida H 2002 Expression of maspin predicts poor prognosis in breast-cancer patients. International Journal of Cancer 100 452-455.

van Agthoven T, Timmermans M, Foekens JA, Dorssers LC \& Henzen-Logmans SC 1994 Differential expression of estrogen, progesterone, and epidermal growth factor receptors in normal, benign, and malignant human breast tissues using dual staining immunohistochemistry. American Journal of Pathology 144 1238-1246.

van Agthoven T, Timmermans M, Dorssers LC \& HenzenLogmans SC 1995 Expression of estrogen, progesterone and epidermal growth factor receptors in primary and metastatic breast cancer. International Journal of Cancer 63 790-793.

van de Rijn M, Perou CM, Tibshirani R, Haas P, Kallioniemi O, Kononen J, Torhorst J, Sauter G, Zuber M, Kochli OR, Mross F, Dieterich H, Seitz R, Ross D, Botstein D \& Brown P 2002 Expression of cytokeratins 17 and 5 identifies a group of breast carcinomas with poor clinical outcome. American Journal of Pathology 161 1991-1996.

van de Vijver MJ, He YD, van't Veer LJ, Dai H, Hart AA, Voskuil DW, Schreiber GJ, Peterse JL, Roberts C, Marton MJ, Parrish M, Atsma D, Witteveen A, Glas A, Delahaye L, van der Velde T, Bartelink H, Rodenhuis S, Rutgers ET, Friend SH \& Bernards R 2002 A gene-expression signature as a predictor of survival in breast cancer. New England Journal of Medicine 347 1999-2009.

van 't Veer LJ, Dai H, van de Vijver MJ, He YD, Hart AA, Mao M, Peterse HL, van der Kooy K, Marton MJ, Witteveen AT, Schreiber GJ, Kerkhoven RM, Roberts C, Linsley PS, Bernards R \& Friend SH 2002 Gene expression profiling predicts clinical outcome of breast cancer. Nature $\mathbf{4 1 5}$ 530-536.

Verkooijen HM, Fioretta G, Vlastos G, Morabia A, Schubert H, Sappino AP, Pelte MF, Schafer P, Kurtz J \& Bouchardy C 2003 Important increase of invasive lobular breast cancer incidence in Geneva, Switzerland. International Journal of Cancer 104 778-781.

Viacava P, Naccarato AG \& Bevilacqua G 1999 Different proliferative patterns characterize different preinvasive breast lesions. Journal of Pathology 188 245-251.

Visscher D, Jimenez RE, Grayson M 3rd, Mendelin J \& Wallis T 2000 Histopathologic analysis of chromosome aneuploidy in ductal carcinoma in situ. Human Pathology 31 201-207.

Vos CB, Cleton-Jansen AM, Berx G, de Leeuw WJ, ter Haar NT, van Roy F, Cornelisse CJ, Peterse JL \& van de Vijver MJ 1997 E-cadherin inactivation in lobular carcinoma in situ of the breast: an early event in tumorigenesis. British Journal of Cancer 76 1131-1133.

Wagner KU, Krempler A, Qi Y, Park K, Henry MD, Triplett AA, Riedlinger G, Rucker III EB \& Hennighausen L 2003
Tsg101 is essential for cell growth, proliferation, and cell survival of embryonic and adult tissues. Molecular and Cellular Biology 23 150-162.

Wahed A, Connelly J \& Reese T 2002 E-cadherin expression in pleomorphic lobular carcinoma: an aid to differentiation from ductal carcinoma. Annals of Diagnostic Pathology 6 349-351.

Walker RA \& Dearing SJ 1999 Expression of epidermal growth factor receptor mRNA and protein in primary breast carcinomas. Breast Cancer Research and Treatment $\mathbf{5 3}$ 167-176.

Wang CS \& Tetu B 2002 Stromelysin-3 expression by mammary tumor-associated fibroblasts under in vitro breast cancer cell induction. International Journal of Cancer 99 792-799.

Warnberg F, Nordgren H, Bergkvist L \& Holmberg L 2001 Tumor markers in breast carcinoma correlate with grade rather than with invasiveness. British Journal of Cancer $\mathbf{8 5}$ 869-874.

Watson PH, Chia SK, Wykoff CC, Han C, Leek RD, Sly WS, Gatter KC, Ratcliffe P \& Harris AL 2003 Carbonic anhydrase $\mathrm{XII}$ is a marker of good prognosis in invasive breast carcinoma. British Journal of Cancer 88 1065-1070.

Watters AD, Going JJ, Cooke TG \& Bartlett JM 2003 Chromosome 17 aneusomy is associated with poor prognostic factors in invasive breast carcinoma. Breast Cancer Research and Treatment 77 109-114.

Weidner N \& Semple JP 1992 Pleomorphic variant of invasive lobular carcinoma of the breast. Human Pathology $\mathbf{2 3}$ 1167-1171.

Wenger CR, Beardslee S, Owens MA, Pounds G, Oldaker T, Vendely P, Pandian MR, Harrington D, Clark GM \& McGuire WL 1993 DNA ploidy, S-phase, and steroid receptors in more than 127,000 breast cancer patients. Breast Cancer Research and Treatment 28 9-20.

West M, Blanchette C, Dressman H, Huang E, Ishida S, Spang R, Zuzan H, Olson JA Jr, Marks JR \& Nevins JR 2001 Predicting the clinical status of human breast cancer by using gene expression profiles. PNAS 98 11462-11467.

Widschwendter M, Berger J, Hermann M, Muller HM, Amberger A, Zeschnigk M, Widschwendter A, Abendstein B, Zeimet AG, Daxenbichler G \& Marth C 2000 Methylation and silencing of the retinoic acid receptor-beta2 gene in breast cancer. Journal of the National Cancer Institute $92826-832$.

Widschwendter M \& Jones PA 2002 DNA methylation and breast carcinogenesis. Oncogene 21 5462-5482.

Woelfle U, Cloos J, Sauter G, Riethdorf L, Janicke F, van Diest P, Brakenhoff R \& Pantel K 2003 Molecular signature associated with bone marrow micrometastasis in human breast cancer. Cancer Research 63 5679-5684.

Wu J, Shen ZZ, Lu JS, Jiang M, Han QX, Fontana JA, Barsky SH \& Shao ZM 1999 Prognostic role of p27Kip1 and apoptosis in human breast cancer. British Journal of Cancer 79 1572-1578.

Xiao G, Liu YE, Gentz R, Sang QA, Ni J, Goldberg ID \& Shi YE 1999 Suppression of breast cancer growth and metastasis by a serpin myoepithelium-derived serine proteinase inhibitor expressed in the mammary myoepithelial cells. PNAS $\mathbf{9 6}$ 3700-3705. 
Yan PS, Chen CM, Shi H, Rahmatpanah F, Wei SH, Caldwell CW \& Huang TH 2001 Dissecting complex epigenetic alterations in breast cancer using $\mathrm{CpG}$ island microarrays. Cancer Research 61 8375-8380.

Yang Q, Sakurai T, Jing X, Utsunomiya H, Shan L, Nakamura Y, Nakamura M, Oura S, Suzuma T, Yoshimura G, Umemura T, Kokawa Y \& Kakudo K 1999 Expression of Bcl-2, but not Bax, correlates with estrogen receptor status and tumor proliferation in invasive breast carcinoma. Pathology International 49 775-780.

Yoneda T 2000 Cellular and molecular basis of preferential metastasis of breast cancer to bone. Journal of Orthopedic Science 5 75-81.

Yoshiji H, Harris SR, Raso E, Gomez DE, Lindsay CK, Shibuya M, Sinha CC \& Thorgeirsson UP 1998 Mammary carcinoma cells over-expressing tissue inhibitor of metalloproteinases-1 show enhanced vascular endothelial growth factor expression. International Journal of Cancer 75 81-87.

Zafrani B, Aubriot MH, Mouret E, De Cremoux P, De Rycke Y, Nicolas A, Boudou E, Vincent-Salomon A, Magdelenat H \& Sastre-Garau X 2000 High sensitivity and specificity of immunohistochemistry for the detection of hormone receptors in breast carcinoma: comparison with biochemical determination in a prospective study of 793 cases.

Histopathology 37 536-545.
Zajchowski DA, Bartholdi MF, Gong Y, Webster L, Liu HL, Munishkin A, Beauheim C, Harvey S, Ethier SP \& Johnson PH 2001 Identification of gene expression profiles that predict the aggressive behavior of breast cancer cells. Cancer Research 61 5168-5178.

Zhao H, Langerod A, Ji Y, Nowels KW, Nesland JM, Tibshirani R, Bukholm IK, Karesen R, Botstein D, Borresen-Dale AL \& Jeffrey SS 2004 Different gene expression patterns in invasive lobular and ductal carcinomas of the breast. Molecular Biology of the Cell 15 2523-2536.

Zhu G, Reynolds L, Crnogorac-Jurcevic T, Gillett CE, Dublin EA, Marshall JF, Barnes D, D’Arrigo C, Van Trappen PO, Lemoine NR \& Hart IR 2003 Combination of microdissection and microarray analysis to identify gene expression changes between differentially located tumour cells in breast cancer. Oncogene 22 3742-3748.

Zhu G, Gilchrist R, Borley N, Chng HW, Morgan M, Marshall JF, Camplejohn RS, Muir GH \& Hart IR 2004 Reduction of TSG101 protein has a negative impact on tumor cell growth. International Journal of Cancer 109 541-547.

Zudaire I, Odero MD, Caballero C, Valenti C, Martinez-Penuela JM, Isola J \& Calasanz MJ 2002 Genomic imbalances detected by comparative genomic hybridization are prognostic markers in invasive ductal breast carcinomas. Histopathology 40 547-555. 